Amasya Ilahiyat Dergisi - Amasya Theology Journal

ISSN 2667-7326 | e-ISSN 2667-6710

Aralık / December 2019, 13: 423-473

\title{
Öğrencilerin İlahiyat Fakültesine Yönelik Görüşleri
}

\section{The Views of the Students Towards the Faculty of Theology}

\section{İlyas Erpay}

Dr. Öğr. Üyesi, Siirt Üniversitesi, İlahiyat Fakültesi, Din Eğitimi Anabilim Dalı Assisstant Professor, Siirt University, Faculty of Theology, Department of

Religion Education

Siirt, Turkey

ilyaserpay@hotmail.com

orcid.org/0000-0003-2350-6998

\section{Makale Bilgisi / Article Information}

Makale Türü / Article Types: Araştırma Makalesi / Research Article

Geliş Tarihi / Received: 30 Mart / March 2019

Kabul Tarihi / Accepted: 26 Ağustos / August 2019

Yayın Tarihi / Published: 30 Aralık / December 2019

Yayın Sezonu / Pub. Date Season: Aralık / December

Sayı / Issue: 13 Sayfa / Pages: 423-473

Atıf / Cite as: Erpay, İlyas. "Öğrencilerin İlahiyat Fakültesine Yönelik Görüşleri [The Views of the Students Towards the Faculty of Theology]". Amasya Ilahiyat Dergisi-Amasya Theology Journal 13 (December 2019): 423-473.

https://doi.org/10.18498/amailad.547095.

İntihal / Plagiarism: Bu makale, en az iki hakem tarafından incelendi ve intihal içermediği teyit edildi. / This article has been reviewed by at least two referees and scanned via a plagiarism software.

Copyright $@$ Published by Amasya Üniversitesi, İlahiyat Fakültesi / Amasya University, Faculty of Theology, Amasya, 05100 Turkey. All rights reserved. https://dergipark.org.tr/amailad. 
424 | İ. ERPAY / Öğrencilerin İlahiyat Fakültesine Yönelik Görüşleri

The Views of the Students Towards the Faculty of Theology

\section{Abstract}

The beginning from the designing phase of the implementation of the religious education activities, determining the appropriate methods, techniques and materials, preparing the educational environment, creating the social areas and ensuring the participation of the students who are the most important stakeholders of the education, will provide to increase in the success level of the theology in the religious education institutions. In this context, it is very important to take the opinions of the students in the social and cultural fields, especially in education and training, to detect of the issues, to reveal the statistical data in the related fields and to benefit from these data. Thus in the light of emerging ideas and offers that it's a necessity to put into implemented of the ideas which will contribute to the solidarity, socialization, information sharing, intellectual development among the students and to create the suitable higher education ground together with the students for more effective religious education. In this study, it has aimed to reveal the perception status of the students of the Faculty of Theology towards the general elements that may affect the education process in the faculty. For this purpose, a survey was conducted with senior students of the Theology Faculty of Siirt University in 2018-2019.

\section{Summary}

The beginning from the designing phase of the implementation of the religious education activities, determining the appropriate methods, techniques and materials, preparing the educational environment, creating the social areas and ensuring the participation of the students who are the most important stakeholders of the education, will provide to increase in the success level of the theology in the religious education institutions. In this context, it is very important to take the opinions of the students in the social and cultural fields, especially in education and training, to detect of the issues, to reveal the statistical data in the related fields and to benefit from these data. Thus in the light of emerging ideas and offers that it is a necessity to put into implemented of the ideas which will contribute to the solidarity, socialization, information sharing, intellectual development among the students and to create the suitable higher education ground together with the students for more effective religious education.

Theology faculties need to be constantly renewed taking into consideration the interests and needs of the students, develop the awareness of the changing world conditions to give an appropriate training to the aims and conditions of education. Therefore, this situation is made it essential to have adequate studies 
done to solve the existing problems. Research shows that many students are coming to theology faculties with great ideals and goals, but they are disappointed.

Today, the instructive-centered understanding of education had changed and instead an understanding of education has been adopted that makes active learning necessary. In other words, a new education system is adopted, which is student-centered, which takes care of using different sources in information acquisition, foresees continuous development. Besides, a new education system has been adopted in which everyone, including instructive, learns throughout life. Religious educational institutions should also benefit from this transformation in education. In general, this understanding of religious education, in which the ongoing instructive is active and the student is passive, must change. Although the roles of the instructive and the learner are different in the theology of higher education institutions during the process of religious education, the parties must be equal in terms of contributing to the educational process as a result of the necessity of being a party. The demands, thoughts and opinions of the students who are one of the parties in religious education on the activities of religious education will contribute significantly to the development of religious education. Furthermore, the development of religious education activities in higher education institutions according to the conditions of the age and the characteristics of the students will play an important role in improving the quality of their output.

In this context, the aim of our study is to determine students' perspectives on curriculum, education system, educational methods and techniques and teaching staffs, administrative structure and faculty in the example of Theological Faculty of Siirt. Another aim of the study is to reveal the purpose of the students' coming to theology and the attitudes of the students who are parties to the religious education process towards theology. The universe of the research is made up the students of Siirt University Theology Faculty. This research was conducted using the screening model which one of the methods of collecting quantitative data. Survey technique was applied to the selected sample group in suitable with the research model. The total number of senior students is 213 which selected as a sample group. However, as a result of examining the questionnaires applied to the sample group, 180 questionnaire forms were found suitable for evaluation.

According to the findings, it is possible to make some evaluations. First of all, when we look at the gender status of the students who prefer the theology faculty undergraduate program, the ratio of female students is higher than male students. When we look at the type of school that students who prefer theology 
426 | İ. ERPAY / Öğrencilerin İlahiyat Fakültesine Yönelik Görüşleri

graduate, it has been observed that the number of arrivals in other high school types increased except for imam hatip high schools in recent years. This means that the faculties of theology, which had previously been forced to be preferred only by imam hatip high school students with the application of the coefficient applied to universities between 1999-2011, it reveals which have started to have a more colorful student profile with the students coming from other high schools. Another finding in research is that a high percentage of the participants $(52.7 \%)$ preferred this section because of occupational anxiety and preferred against their will (family wish). $43.4 \%$ of respondents who prefer our religion to learn and serve religion correctly and comprehensively. This ratio is low than reason of choice from necessity. Finally, there are no participant who prefer faculty of theology to become cleric(imam).

About the teaching staffs; although the students who participated in the study generally considered the instructors to be sufficient in their field, they found them inadequate in the use of appropriate methods and techniques and materials. The participants think that philosophy (85\%) and formation $(97.2 \%)$ lessons which given in the faculty of theology are necessary and useful. Participants think that educational opportunities in the faculty of theology provision to a sufficient degree their expectations. At the same time, studying in the faculty of theology led to a change of opinion in the majority of students $(84.4 \%)$. Most of the participants have described this change of opinion as personality change and having a critical thinking with knowledge change.

In the light of these results, it is possible to present some suggestions. Students should be given opportunities to improve from every angle, platforms where students can freely express their ideas should be established, faculty should be turned into a place where education and socialization are carried out together. Collaborate should be done with students in these issues, the relationship that between faculty administration and students should be strengthened. If necessary, the faculty student representative should be included in the faculty boards. In addition, lessons should be enriched in content, lesson materials should be updated. Teaching staffs should review telling lecture strategy, methods and techniques, should diversify the lecture tools and materials in accordance with the subjects. In addition, according to the findings of the research, it is seen that students have difficulty in Arabic lessons. Language teaching methods should be applied, new teaching materials with methods and techniques should be determined in Arabic teaching. On the other hand, theology programs should be revised again and organized according to the conditions of the day and the professional differentiation. Curriculums should create according to their service areas in the theology faculties, Students should 
take lessons according to the institutions in which they will work, and they should be directed to more practice.

Consequently, in theology faculties which high religious education institutions the role of students is important for the development and transformation of the theology faculties and to be an ideal institution of higher religious education. In this context, it is important to apply more frequently to student opinions, to involve students in the process and to evaluate the appropriate opinions and suggestions of the students.

Keywords: Religious Education, Faculty of Theology, Higher Religious Education, Educational Status, Student Perception.

\section{Öz}

\section{Öğrencilerin İlahiyat Fakültesine Yönelik Görüşleri}

Yüksek din eğitimi kurumlarında, din öğretimi faaliyetinin yürütülmesinin tasarlama aşamasından başlayarak, uygun yöntem, teknik ve materyallerin belirlenmesi, eğitim ortamının hazırlanması, sosyal alanların oluşturulması konularında eğitimin en önemli paydaşı olan öğrencilerin katılımının aktif olarak sağlanması, ilahiyatlardaki akademik başarıya ve eğitimin niteliğine katkı sağlayacağı muhakkaktır. Bu bağlamda öğrencilerin başta eğitim-öğretim olmak üzere, sosyal ve kültürel alanlardaki düşüncelerinin alınması, sorunların tespit edilmesi, ilgili alanlarda istatistiki verilerin ortaya konması ve bu verilerden yararlanılması oldukça önem arz etmektedir. Nitekim ortaya çıkan fikir ve düşünceler ile öğrencilerden gelebilecek teklifler ışığında öğrenciler arasında dayanışmaya, sosyalleşmeye, bilgi paylaşımına, öğrencilerin entelektüel gelişimine katkı sağlayacak fikirlerin uygulamaya konulması ve din öğretiminin daha etkin yürütülmesi için uygun yükseköğretim zemininin öğrenci ile birlikte oluşturulması gerekliliktir. Bu çalışmada ilahiyat fakültesi son sınıf öğrencilerinin fakülte içerisinde eğitim-öğretim sürecini etkileyebilecek genel unsurlara karşı görüşlerini ortaya koymak amaçlanmış olup, bu amaç doğrultusunda Siirt Üniversitesi İlahiyat Fakültesi 2018-2019 eğitim öğretim yılı son sınıf öğrencileri ile anket çalışması yapılmıştır.

Anahtar Kelimeler: Din Eğitimi, İlahiyat Fakültesi, Yüksek Din Öğretimi, Eğitim Durumu, Öğrenci Alg1sı.

\section{Giriş}

İlahiyat, bir düşünce alanıdır ve Tanrı'nın ya da evrenin dinsel açıklamasını, akıl merkezli kalarak gerçekleştiren entelektüel bir etkinliktir. İlahiyat, Tanri'ya duyulan inancın tutarlı ve anlamlı 
428 I İ. ERPAY / Öğrencilerin İlahiyat Fakültesine Yönelik Görüşleri

yorumlanmasını maksat tutmaktadır. ${ }^{1}$ İlahiyat fakülteleri yüksek din eğitim kurumlarında birliği sağlamak, başta İslam dini olmak üzere, çeşitli dinleri bilimsel yöntemlerle incelemek ve öğretmek amacıyla kurulmuş yükseköğretim kurumlarıdır. İlahiyat fakülteleri bilimsel bilgi üretmekle birlikte dini bilgiyi en üst seviyede aktaran kurum olarak din eğitim faaliyeti de yürütmektedir. Bu anlamda ülkemizde cumhuriyet sonrası ihtiyaç duyulan din dersi öğretmenleri ile müftü ve vaizleri yetiştirme, dini alanda bilimsel bilgi üretme yetkisi ilahiyat fakültelerine verilmiştir. ${ }^{2}$ Genelde eğitim özelde din eğitimi faaliyetleri sürecinde taraflar (öğreten-öğrenen) günün şartlarına, öğrencilerin ve öğretenlerin ilgilerine ve beklentilerine, gelişen eğitim teknolojileri ile materyallerinin optimal anlamda kullanımına göre yeniden şekillenmekte ve gelişmektedir. Gelişmeler karşısında pozisyonlarını gözden geçirmeyen, yeni şartlar doğrultusunda kendisini geliştirip yenilemeyen kurumlar tarihten çekilmek zorunda kalmışlardır. Eğitim tarihimize baktığımızda bunun açık örneğini görmekteyiz. Osmanlı Medreseleri dini referanslı olsalar da bu sondan kurtulamamışlardır. Bugün faaliyet yürüten yüksek din eğitim kurumları, çağın dini ihtiyaçlarına cevap verme noktasında çağı anlayıp yorumlayan, stratejik ve konjonktürel gelişmeleri çözümleyebilen ve günün problemlerine karşı doğru dini çözümler üretecek ilahiyatçılar yetiştirmek için gerekli yapısal ve akademik dönüşümü gerçekleştirmelidir. ${ }^{3} \mathrm{Bu}$ anlamda yükseköğretim kurumlarında yapılan din eğitimi faaliyetinin çağın şartlarına, öğrencilerin özeliklerine göre geliştirilmesi, çıtılarının kalitesini arttırmada öncü rolü üstlenecektir.

İlahiyat fakültelerinde yetişen öğretim elemanları öğreticinin genel olarak aktif, öğrencinin pasif olduğu bir eğitim sisteminde yetişmişler, bu eğitim yöntemi ile din eğitim hizmeti yürütmüşler ${ }^{4}$ ve bu durum bazılarında hala devam etmektedir. Günümüzde bu anlayış değişmeli, din eğitimi faaliyeti sürecinde yüksek eğitim kurumları olan ilahiyatlarda öğreten ve öğrenen olarak her ne kadar roller farklı olsa da

1 Necdet Subaşı, "İlahiyat Nedir", Tezkire, Düşünce, Siyaset, Sosyal Bilim Dergisi 31-32 (2003): 66.

2 Suat Cebeci, "Cumhuriyet Dönemi Yüksek Öğretimde Din Eğitimi", Ankara Üniversitesi İlahiyat Fakültesi Dergisi 39/2 (1999): 229.

3 Ali Rıza Gül, "Yüksek Din Eğitimi Kurumlarında Değişim ve Yenilenmenin Gerekçeleri", Eskişehir Osmangazi Üniversitesi İlahiyat Fakültesi Dergisi 5 (2016): 9.

4 Adnan Demircan, Türkiye'nin İlahiyat Sorunu (İstanbul: Beyan, 2015), 39. 
taraflar, taraf olmanın gerekliliği sonucu eğitim öğretim sürecine katkı anlamında eşit olmalıdırlar. Din öğretiminde taraflardan biri olan öğrencilerin din eğitimi faaliyeti konusundaki talepleri, düşünceleri ve görüşlerinin din eğitimi faaliyetine yansıması din eğitiminin gelişimine önemli katkılar sağlayacaktır.

Günümüzde, öğreten merkezli eğitim anlayışı değişerek yerine öğrenmeyi öğrenmeye dayalı, bilgi edinmede farklı kaynaklardan yararlanmanın önemsendiği ve sürekli gelişimi öngören bir sistem olan, aktif öğrenmeyi gerekli kılan öğrenci merkezli eğitim anlayışı benimsenerek, öğretenin de yaşam boyu öğrendiği bir döneme girilmiştir.

İlahiyat fakültelerinin, eğitimin amaçları ve koşullarına uygun bir eğitim verebilmesi için öğrencilerin ilgi ve ihtiyaçlarını dikkate alarak sürekli olarak yenilenmeye, değişen dünya şartlarından haberdar olarak gelişmeye ihtiyacı vardır. Dolayısıyla bu durum mevcut sorunların çözümü için yeterli çalışmaların yapılmasını zaruri hale getirmektedir. Yapılan araştırmalar, birçok öğrencinin ilahiyat fakültelerine büyük ideallerle ve hedeflerle gelmekte olduklarını, ancak hayal kırıklığına uğradıklarını göstermektedir. ${ }^{5}$

Din eğitimcileri öğretim süreçlerini ve bu süreçte işe koşulacak unsurları tasarlarken, uygularken, değerlendirirken öğrencilerin genel özelliklerini, giriş yeterliliklerini, öğrenme stratejileri ve sitillerinin yanı sıra sosyo-ekonomik ve kültürel alt yapılarını, aile çevrelerini, ilgi ve beklentilerini vb. özelliklerini analiz etmelidirler. ${ }^{6}$ Bizde ve Batı dünyasında din eğitimine getirilen en büyük eleştiri öğrencinin görmezden gelinmesi olmaktadır. Günümüzde eğitimin ve din eğitiminin her aşamasında öğrenciye görelilik şart haline gelmiştir. ${ }^{7}$

Yüksek eğitim kurumlarında din eğitimi noktasında yapılan birçok bilimsel çalışma bulunmaktadır. 2000 ile 2011 yılları arasında bahse konu yapılan çalışmalar arasında; Koç'un (2003) "İlâhiyat Fakültesi (Illâhiyat

5 Mustafa Köylü, “OMÜ İlahiyat Fakültesine Devam Eden Yabancı Uyruklu Öğrencilerin Fakülte Hakkındaki Düşünce, Sorun ve Beklentileri", Ondokuz Mayıs Üniversitesi İlahiyat Fakültesi Dergisi 12/12-13 (2001): 133.

6 Mehmet Korkmaz, Din Öğretimi Teknolojisi ve Materyal Geliştirme (Kayseri: Kimlik Yayınları, 2017), 32.

7 Cemal Tosun, Din Eğitimi Bilimine Giriş (Ankara: Pegem Akedemi, 2002), 121. 
430 । İ. ERPAY / Öğrencilerin İlahiyat Fakültesine Yönelik Görüşleri

Lisans Programı) Öğrencilerinin Sorunları ve Beklentileri", 8 Taştan, Kuşat, Çelik'in (2001) “Üniversite Düzeyinde Din Öğretimi Alan Öğrencilerde Eğitim Sürecinde Oluşan Tutum ve Davranış Değişiklikleri (Erciyes Üniversitesi İlahiyat Fakültesi Örneği)", ${ }^{9}$ Korkmaz'ın (2010) "İlahiyat Fakültesi Öğrencilerinin Fakülteyi Tercih Nedenleri: Erciyes Üniversitesi İlahiyat Fakültesi Örneği"10 yer almaktadır.

2011 yılı sonrasında yapılan çalışmalar arasında ise Taştekin'in (2013) "Yeni Kurulan İlahiyat Fakültelerinin Öğrenme Ortamına Yönelik Öğrenci Algıları",11 Uçar'ın (2017) "İlahiyat Fakültesi Öğrencilerinin Profili, Akademik Eğilimleri ve Aldıkları Eğitime İlişkin Memnuniyet Algıları (İnönü Üniversitesi Örneği)"12 ve Ö̈zenç'in (2017) “Son Sinıf Öğrencilerine Göre Beklentileri Karşılama ve Mesleki Hayata Hazırlamada İlahiyat Fakültelerinde Eğitim (Dicle Üniversitesi Örneği)"13 gibi son çalışmalar yer almaktadır. Çalışmada, daha önce bu alanda yapılan çalışmaların verileriyle, Siirt İlahiyat Fakültesi özelinde yapılan çalışma verileri karşılaştııılarak, Siirt İlahiyat Fakültesi özelinde ortaya çıkan tespitlerin genel tespitler içerisindeki yeri irdelenmeye çalışılmıştır. Ayrıca 1999 yılı üniversitelere geçişte kat sayı uygulaması sonrası ilahiyat fakültelerinde ortaya çıkan tablo ile kat sayının ortadan kalktığ1 2011 yılı sonrası çalışma verilerinin karşılaştırma olanağı bulunmuştur.

Eğitimin unsuru olan öğrenciler eğitim ortamına, öğretim yöntem ve tekniklerine, müfredata vb. eğitim sürecine yanıt verirler, karşı

8 Ahmet Koç, “İlâhiyat Fakültesi (İlâhiyat Lisans Programı) Öğrencilerinin Sorunları ve Beklentileri”, M.Ü. İlâhiyat Fakültesi Dergisi 25 (2003): 25-64.

9 Abdulvahap Taştan vdğr., "Üniversite Düzeyinde Din Öğretimi Alan Öğrencilerde Eğitim Sürecinde Oluşan Tutum ve Davranış Değişiklikleri (Erciyes Üniversitesi İlahiyat Fakültesi Örneği)", Erciyes Üniversitesi Sosyal Bilimler Enstitüsü Dergisi 1/11 (01 Aralık 2001): 169-192.

10 Mehmet Korkmaz, “İlahiyat Fakültesi Öğrencilerinin Fakülteyi Tercih Nedenleri: Erciyes Üniversitesi İlahiyat Fakültesi Örneği", Bilimname 2010/1 (01 Mart 2010).

11 Osman Taştekin, "Yeni Kurulan İlahiyat Fakültelerinin Öğrenme Ortamına Yönelik Öğrenci Algıları", Usûl İslam Araştırmaları 19 (2013): 139-184.

12 Recep Uçar, "İlahiyat Fakültesi Öğrencilerinin Profili, Akademik Eğilimleri ve Aldıkları Eğitime İlişkin Memnuniyet Algıları (İnönü Üniversitesi Örneği)”, İnönü Üniversitesi İlahiyat Fakültesi Dergisi 8/2 (27 Aralık 2017): 97-170.

13 Ali Özenç, “Son Sınıf Öğrencilerine Göre Beklentileri Karşılama ve Mesleki Hayata Hazırlamada İlahiyat Fakültelerinde Eğitim (Dicle Üniversitesi Örneği)", International Journal of Kurdish Studies 3/January (2017): 1-30. 
koyarlar, uzlaşırlar veya tepki gösterirler. ${ }^{14} \mathrm{Bu}$ noktayı nazardan hareketle yükseköğretimde din eğitimi faaliyetinin yürütülmesinin planlanması aşamasından, gerekli yöntem, teknik ve materyallerin belirlenmesi, eğitim ortamının hazırlanması, sosyal alanların oluşturulması vb. konularda aktif öğrenci katılımının sağlanması, öğrencilerin düşüncelerinin alınması, sorunların tespit edilmesi, istatistiki verilerden yararlanılması, gelişime katkı sağlayacak fikirlerin uygulamaya konulması ve din eğitiminin daha etkin yürütülmesi için uygun yükseköğretim zemininin öğrenciyle birlikte oluşturulması bir gerekliliktir. Bu bağlamda araştırmanın temel problemi ilahiyatta eğitim faaliyetinin daha sağlıklı bir şekilde yürütülmesi için öğrenci görüşlerinin önemli olduğu bu dönemde Siirt İlahiyat Fakültesi özelinde öğrencilerin, Siirt İlahiyat Fakültesine yönelik tutumlarının belirlenmesidir. İlahiyat fakültesinde uygulanan müfredat ve eğitim ortamı, öğretim elemanları, uygulanan yöntem ve teknikler, yönetim öğrenci ilişkisi, verilen eğitimin yeterlilik durumu, derslere karşı öğrenci tutumu gibi unsurlar alt problemler olarak ele alınmıştır.

\section{Araştırmanın Amacı}

Çalışmamızın öncelikli amacı Siirt İlahiyat Fakültesi örneğinde öğrencilerinin müfredat, eğitim sistemi, eğitim yöntem ve teknikleri ile öğretim elemanlarına, idari yapıya, fakülteye bakış açılarını tespit etmektir. Diğer bir amacı ise ilahiyata gelen öğrencilerin ilahiyata geliş amaçlarını ve din eğitim sürecinde taraf olan öğrencilerin ilahiyata karşı tutumlarını ortaya koymaktır.

\section{Araştırmanın Önemi}

İlahiyat Fakültelerinde yetişen din görevlileri aldıkları din eğitiminin sahada birebir uygulayıcısıdırlar. Nitekim ilahiyattan mezun olanlar ilahiyattaki müfredat, öğretim elemanları, yöntem ve teknikler, sosyal etkinlikler, idare öğrenci ilişkileri vb. etkenlerin çıtısıdır. Ayrıca her mezun olan öğrenci mezun olduğu üniversitenin fakültesiyle özdeşleşmekte, hayat boyu o vasfı taşımaktadır. Dolayısıyla mezun olduğu ilahiyat fakültesiyle özdeşleşen birey hizmet ettiği kurumda mezun olduğu fakültenin bir temsilcisi konumundadır. Netice itibariyle eğitim aldığı kurumun özelliklerini, hocalardan aldığı eğitim yöntem ve tekniklerini eğitim verdiği kuruma yansıtması kaçınılmazdır. Bu nedenle

14 Necla Kurul Tural, “Öğrenci Başarısında Etkili Okul Değişkenleri ve Eğitimde Verimlilik", Ankara Universitesi Egitim Bilimleri Fakultesi Dergisi 1/35 (2002), 40. 
432 | İ. ERPAY / Öğrencilerin İlahiyat Fakültesine Yönelik Görüşleri

ilahiyat mezunlarının eğitimin amaçlarına ve koşullarına uygun bir din eğitimi verebilmelerine en büyük katkıyı sunan ilahiyatlardaki aldıkları din eğitimidir. Bu bağlamda bugünün öğrencileri yarının öğreticileridir. Dolayısıyla öğrenci görüş ve düşüncelerinin alınarak din eğitiminin yükseköğretim düzeyinde yapılan din eğitim faaliyetleri içerisinde değerlendirilmesi açısından öğrenci gözünden sorunların oryaya konulmasının önemi bir kez daha ortaya çıkmıştır.

\section{Araştırmanın Sınırlılığı}

Araştırmanın sınırlılığını, evrenin sorununa en uygun kesim olduğu düşünülen, toplamda 213 kişi olan Siirt Üniversitesi İlahiyat Fakültesi son sınıf öğrencileri oluşturmaktadır. Ayrıca araştırmada kullanılacak veri toplama araçları anket tekniği ile sınırlandırılmıştır.

\section{Yöntem}

\subsection{Araştırmanın Modeli}

$\mathrm{Bu}$ araştırma nicel verileri toplama yöntemlerinden biri olan tarama modeli kullanılarak yapılmıştır. Seçilen örneklem gurubundaki kişilere araştırma modeline uygun olarak anket tekniği uygulanmış, elde edilen bulgular betimlenerek mevcut durum ortaya konmaya çalışılmıştır.

\subsection{Evren ve Örneklem}

Araştırma evreni, 2018-2019 eğitim-öğretim yılı Siirt Üniversitesi İlahiyat Fakültesi ilahiyat lisans programına devam eden öğrenciler oluşturmaktadır. Müfredatın tamamını görmeleri, fakülte ve hocaların tamamını tanımaları, fakültenin avantaj ve dezavantajına hakim olmaları nedeniyle fakülteyi bütün yönleriyle değerlendirebilmek için yeterli bilgi ve birikim düzeyine sahip oldukları düşünüldügünden olasılıklı olmayan örnekleme türlerinden olan amaçlı örnekleme tekniği ile ilahiyat bölümü son sınıf öğrencileri, örneklem olarak seçilmiştir. 20182019 öğretim yılında Siirt İlahiyat Fakültesine devam eden öğrenci sayısı 950'dir. Örneklem grubu olarak seçilen son sınıf öğrencilerinin sayısı ise toplam 213 dür. Örneklem grubuna uygulanan anketlerin incelenmesi sonucu 180 anket formu değerlendirmeye uygun bulunmuştur.

\subsection{Araştırma Verilerin Toplanması ve Analizi}

Araştırmada verileri toplamak amaci ile anket tekniği kullanılmıştır. Ankette toplamda 27 soru sorulmuş olup bu soruların oluşturulmasında daha önce bu alanda yapılmış olan; “Özenç, (2017). Son Sını Öğrencilerine Göre Beklentileri Karşılama ve Mesleki Hayata Hazırlamada 
Illahiyat Fakültelerinde Eğitim (Dicle Üniversitesi Örneği)15 ve Koç, (2003). İlâhiyat Fakültesi (İlâhiyat Lisans Programı) Öğrencilerinin Sorunları ve Beklentileri Ilâhiyat Fakültesi (İlâhiyat Lisans Programı) Öğrencilerinin Sorunları ve Beklentileri"16 çalışmalarından yararlanılmıştır. Ankete 213 öğrenci katılmış olup; ancak 213 anketin 180'i değerlendirmeye alınmış, 33 anket ise büyük ölçüde boş birakıldığı için değerlendirmeye alınmamıştır. Elde edilen ham veriler bilgisayar ortamında "SPSS 20 Programı" ile değerlendirilmiş olup, iki ayrı analiz yapılmıştır. Bunlardan ilki betimsel istatistik olan frekans dağılımı analizidir. Diğeri ise çapraz analiz ve Ki-Kare testleridir. Yüzde analizi ile ankete katılan öğrencilerin müfredat, eğitim sistemi, eğitim yöntem ve teknikleri, ilahiyata geliş amaçları vs. hakkındaki görüşlerine yönelik elde edilen verilerin yüzdelik dağılımına bakılmıştır. Çapraz analiz yöntemi ile de değişkenler arasındaki ilişkiler incelenmiştir.

\section{Bulgular}

\subsection{Katılımcıların Kişisel Özelliklerine Yönelik Bulgular}

Araştırmada öğrencilerin cinsiyet, mezun olduğu okul türü, ailelerinin gelir durumu, ilahiyat fakültesini seçme nedenleri ele alınmış ve konuyla ilgili betimsel analizler aşağıda verilmiştir.

\section{Tablo 1. Öğrencilerin Cinsiyete Göre Dağılımı}

\begin{tabular}{|c|c|c|}
\hline Cinsiyetiniz & Kişi Sayısı & Yüzde \\
\hline Kiz & 103 & 57,2 \\
\hline Erkek & 77 & 42,8 \\
\hline Toplam & 180 & 100,0 \\
\hline
\end{tabular}

Araştırma kapsamındaki öğrencilerin cinsiyet dağılımı incelendiğinde (Tablo 1) öğrencilerin \%57,2'sini kadın kız öğrenciler, $\% 42,8$ 'ini ise erkek öğrenciler oluşturmaktadır. Yapılan çalışmalara bakıldığında 2000'li yıllara kadar erkek oranının fazla olduğu gözlenirken ${ }^{17}$ son yıllarda ilahiyatı tercih kadın oranlarının erkekten daha fazla olduğu görülmektedir. Korkmaz'ın yapmış olduğu araştırmada Erciyes Üniversitesi İlahiyat Fakültesi cinsiyet dağılımını

15 Özenç, “Son Sınıf Öğrencilerine Göre Beklentileri Karşılama ve Mesleki Hayata Hazırlamada İlahiyat Fakültelerinde Eğitim (Dicle Üniversitesi Örneği)".

16 Koç, "İlâhiyat Fakültesi (İlâhiyat Lisans Programı) Öğrencilerinin Sorunları ve Beklentileri".

17 Murat Yıldız, İlahiyat Fakültesi Öğrencilerinin Psikososyal Özellikleri (İzmir: Tibyan Yayıncilik, 2003), 19. 
434 I İ. ERPAY / Öğrencilerin İlahiyat Fakültesine Yönelik Görüşleri

\%72' si kadın, \%28'i de erkek olarak tespit etmiştir. ${ }^{18}$ Taştekin'in çalışmasında yer alan katılımcıların \%58,3'ü kadın, \%41,7'si erkektir. ${ }^{19}$

2002-2003 öğretim yılı Yüksek Öğretim Kurumu istatistiğine göre 4.505 kadın, 4.556 erkek eğitim görmekteyken, aynı öğretim yılında yeni kayıt yaptıran öğrencilerin 726'sı kadın, 666'sı erkektir. ${ }^{20}$ Yüksek Öğretim Kurumu (YÖK) 2018 istatistiklerine göre ilahiyat fakültelerinin normal öğretiminde 17625 erkek, 26621 k1z öğrenci okurken, ikinci öğretimlerinde 11275 erkek öğrenci, 14275 k1z öğrenci okumaktadır. ${ }^{21}$ Görüldüğü üzere 2000'li yıllarda ilahiyatlarda okuyan k1z ve erkek öğrenci oranı eşitken, sonrası ilahiyatları tercih eden kız öğrenci oranında büyük artış gözlenmiş ve bu gün ilahiyat fakültelerinde okuyan öğrencilerin yaklaşık 3/2'sini kadınlar oluşturmaktadır.

Tablo 2. Öğrencilerin Mezun Olduğu Okul Türü

\begin{tabular}{|l|c|c|}
\hline \multicolumn{1}{|c|}{ Mezun olduğunuz okul türü } & Kişi Sayısı & Yüzde \\
\hline Düz Lise & 47 & 26,1 \\
\hline İmam Hatip Lisesi & 108 & 60,0 \\
\hline Meslek Lisesi & 15 & 8,3 \\
\hline Açı Öğretim Lisesi & 10 & 5,6 \\
\hline \multicolumn{1}{|c|}{ Toplam } & 180 & 100,0 \\
\hline
\end{tabular}

İlahiyat fakültesinde okuyan son sınıf öğrencilerin \%26,1'i düz lise, \%60'1 imam hatip lisesi, \%8,3'ü meslek lisesi ve \%5,6's1 ise açı öğretim lisesi mezunudur. Çalışmada dikkatimizi çeken düz liseden mezun olup ilahiyatı tercih edenlerin oranındaki artış olmuştur. Osman Taştekin'in çalışmasında ${ }^{22}$ düz lise ve Anadolu lisesi beraber \%15,5 oranındayken, bu çalışmada oran \%26,1'e çıkmıştır. 1999-2011 yılları arasında uygulanan katsayı uygulamasının üniversiteye yerleştirmede ${ }^{23}$ önemli etkenlerinden birisi imam hatip liselerinde okuyanların ilahiyat harici fakültelere

18 Korkmaz, “İlahiyat Fakültesi Öğrencilerinin Fakülteyi Tercih Nedenleri: Erciyes Üniversitesi İlahiyat Fakültesi Örneği", 170.

19 Taştekin, "Yeni Kurulan İlahiyat Fakültelerinin Öğrenme Ortamına Yönelik Öğrenci Algiları", 149.

20 Koç, "İlâhiyat Fakültesi (İlâhiyat Lisans Programı) Öğrencilerinin Sorunları ve Beklentileri", 31.

21 "Yükseköğretim Kurulu,Yükseköğretim Bilgi Yönetim Sistemi", erişim: 16 Mart 2019, https://istatistik.yok.gov.tr/.

22 Taştekin, "Yeni Kurulan İlahiyat Fakültelerinin Öğrenme Ortamına Yönelik Öğrenci Algiları", 150.

23 Bk. M. Kadir Doğan - Tolga Yuret, “Üniversitelere Yerleşmede Farklı Katsayı Uygulamasının Etkileri”, Ankara Üniversitesi SBF Dergisi 70/1 (2015): 195-220. 
gidememeleri iken, düz lise ve meslek lisesi mezunlarının da ilahiyat fakültelerine girememeleri olmuştur. Yukarıda verilere göre 2011 sonrası ise düz lise ve diğer meslek liselerinden ilahiyat fakültelerine girişte ciddi oranda artış görülmektedir. Bu durum ilahiyat fakültelerindeki öğrenci profili açısından çeşitliliğe yol açmakta ve fakülteleri her kesime hitap eder duruma getirmektedir.

\section{Tablo 3. Öğrenci Ailelerinin Gelir Durumu}

\begin{tabular}{|c|c|c|}
\hline Ailenizin gelir durumu & Kişi Sayısı & Yüzde \\
\hline $0-2020$ & 85 & 47,2 \\
\hline $2021-3200$ & 49 & 27,2 \\
\hline $3201-5000$ & 36 & 20,0 \\
\hline 5001- Üzeri & 10 & 5,6 \\
\hline Toplam & 180 & 100,0 \\
\hline
\end{tabular}

Öğrenci ailelerinin gelir durumu incelendiğinde ise $\% 47,2$ oranında ailenin gelir durumu asgari ücret ve altı iken, \%27,2'si “2021-3200” TL, $\% 20$ 'si “3201-5000"TL arasında bir gelire sahiptir. \%5,6 oranındaki ailenin geliri ise 5001TL ve üzeridir. $2021 \mathrm{TL}$ ile $5000 \mathrm{TL}$ arası gelire sahip ailelerin durumunu orta gelirli olarak düşünebiliriz ki bu duruma göre ilahiyat okuyan öğrencilerin ailevi gelirlerinde orta düzeyin altında gelir sahibi olanların oranı $(\% 47,2)$ ile orta düzey gelir sahibi olanların oranı toplamı $(\% 47,2)$ birbirine eşittir. 5001 TL üzeri gelire sahip olan aileleri orta düzeyin üstünde gelir sahibi olarak değerlendirebiliriz ki bu oran diğer oranlara göre çok az görünmektedir.

Tablo 4. Öğrencilerin İlahiyat Fakültesini Seçme Nedeni

\begin{tabular}{|c|c|c|}
\hline İlahiyatı seçme nedeniniz & Kişi Sayısı & Yüzde \\
\hline Ailem İstediği İçin & 34 & 18,9 \\
\hline Dinimizi Doğru ve Kapsamlı Öğrenmek İçin & 59 & 32,8 \\
\hline Daha Kolay Meslek Sahibi Olmak İçin & 17 & 9,4 \\
\hline Dine Hizmet İçin & 19 & 10,6 \\
\hline Öğretmen Olmak İicin & 29 & 16,1 \\
\hline İmam Olmak için & 0 & 0 \\
\hline Sinav Sisteminden Dolay 1 & 15 & 8,3 \\
\hline Diğer & 7 & 3,9 \\
\hline Toplam & 180 & 100,0 \\
\hline
\end{tabular}

Öğrencilerin ilahiyat fakültelerini tercih etme nedenleri incelendiğinde "ailelerin istemesi ve dinin doğru ve kapsamlı bir şekilde öğrenmek" ilk sırada yer almaktadır. Buna göre öğrencilerin \%32,8'i dini daha doğru ve kapsamlı şekilde öğrenmek için, \%18,9'u aileleri istediği 
436 | İ. ERPAY / Öğrencilerin İlahiyat Fakültesine Yönelik Görüşleri

için, \%16,1'i öğretmen olmak için, \%10,6'sı dine hizmet etmek için ve $\% 8,3^{\prime} \ddot{\mathrm{u}}$ ise sinav sisteminden dolayı tercih etmişlerdir. \%3,9'u ise tercih nedenlerinin diğer sebeplerden ötürü olduğunu belirtmiştir. Diğer sebepleri belirtenler, Din Kültürü ve Ahlak Bilgisi Öğretmenliği bölümünün kaldırılması ve ilahiyatı sevdiği, istediği için seçtiğini ifade edenler oluşturmuştur. Ancak ilahiyatı imam olmak için tercih eden kimse olmamıştır. Koç'un çalışmasında ${ }^{24}$ ilahiyatı, dini doğru öğrenmek için seçenler \%28,5, bu çalışmada dinimizi doğru ve kapsamlı öğrenmek için seçen öğrencilerin oranı \%32,8 olmuştur. Koç'un çalışmasına ${ }^{25}$ göre öğrencilerin 1/4'ü İlâhiyat Lisans Programı'nı seçmelerinde en önemli faktörün mevcut Öğrenci Seçme Sınavı Sistemi olduğunu belirtirken, bu çalışmada oran \%8,3’te kalarak önemli derecede azalmış gözükmektedir. İlahiyatı aile isteği ile seçenlerin oranı Turan ve Naziroğlu'nun yaptı̆̆ ortak çalışmada ${ }^{26} \% 7,9$ oranında, Okumuş'un yaptığı çalışmada ${ }^{27} \% 6,3$ oranında iken bu çalışmada oran \%18,9'a kadar yükselmiştir. Bunun nedenleri arasında ailelerin gelir durumunun orta düzey altı ve orta düzey olması, son dönemlerde ilahiyat mezunlarının kısa sürede atanmaları, aileler tarafından çocuklarının hem dinini öğrenmeleri ve yaşamaları istenirken, diğer taraftan dünyevi ihtiyaçlarını karşılayacak bir meslek sahibi olma arzuları olarak düşünülebilir. Bu durumda ailelerin çocuklarını ilahiyata sevk etmelerinde atanmanın önemli bir yerinin olduğu söylenebilir.

Diğer bir konu, imamlığın ilahiyat bitirenler tarafından pek tercih edilmediği sonucudur. Diyanet İşleri Başkanlığı bünyesinde istihdam edilen din görevlilerinin eğitim düzeyi açısından dağılımına bakıldığında, ilahiyat fakültesi mezunlarının oranının düşük olması da bu görüşü desteklemektedir. 2010 yılı itibariyle kurumdaki toplam personel sayısının \% 29,1'i İmam Hatip Lisesi (İHL) mezunu iken, İlahiyat Ön Lisans mezunlarının oranı \% 37,5 ve ilahiyat fakültesi

24 Koç, “İlâhiyat Fakültesi (İlâhiyat Lisans Programı) Öğrencilerinin Sorunları ve Beklentileri", 34.

25 Koç, "İlâhiyat Fakültesi (İlâhiyat Lisans Programı) Öğrencilerinin Sorunları ve Beklentileri", 59.

26 İbrahimTuran - Bayramali Nazıroğlu, "İlahiyat Fakültesine Yeni Gelen Öğrencilerin Sorun ve Beklentileri: OMÜ İlahiyat Fakültesi Örneği", Journal of International Social Research 2015, 469.

27 Ejder Okumuş, “İlahiyat Fakültesi Öğrencilerinin Problemleri -Dicle Üniversitesi Örneği-", Değerler Ĕ̆itimi Dergisi 5/13 (2007): 72. 
mezunlarının oranı ise \% 10,9'dur. ${ }^{28}$ Toplam personel sayısının 2017 yılı itibariyle oranı ise \%17,4'ü imam hatip lisesi mezunu iken, ilahiyat ön lisans mezunlarının oranı $\% 52,7$ ve ilahiyat fakültesi mezunlarının oranı ise $\% 27,4^{\prime}$ tür. ${ }^{29}$ Ancak çalışmada hiç kimsenin imam olmak için ilahiyatı tercih etmemesinin nedeni arasında ilahiyat ön lisans ve imam hatip lisesi mezunlarının imam olarak atanabilmeleri olabileceği gibi, imamların çalışma koşulları, sosyal-kültürel sorunlar, imamlık yaptıkları yerleşim biriminin fiziki yapısındaki eksikliklerden kaynaklanan sorunlar ${ }^{30}$ da etken olabilir.

Tablo 5. Öğrencilerin Cinsiyetine Göre İlahiyat Fakültesini Seçme

Nedeni

\begin{tabular}{|c|c|c|c|c|c|c|c|c|}
\hline \multirow[b]{2}{*}{ 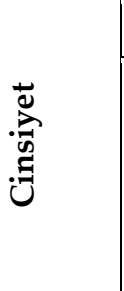 } & \multicolumn{7}{|c|}{ İlahiyatı Seçme Nedeniniz } & \multirow[t]{2}{*}{ Toplam } \\
\hline & $\begin{array}{c}\text { Ailemin } \\
\text { İsteği }\end{array}$ & \begin{tabular}{|c|} 
Dinimizi \\
Doğru ve \\
Kapsamlı \\
Öğrenmek
\end{tabular} & \begin{tabular}{|c|} 
Daha \\
Kolay \\
Meslek \\
Sahibi \\
Olmak
\end{tabular} & \begin{tabular}{|c|} 
Dine \\
Hizmet
\end{tabular} & $\begin{array}{c}\text { Öğretmen } \\
\text { Olmak }\end{array}$ & $\begin{array}{c}\text { Sinav } \\
\text { Sisteminden } \\
\text { Dolayı }\end{array}$ & Diğer & \\
\hline \multirow[t]{2}{*}{ Kadın } & 22 & 32 & 8 & 13 & 16 & 8 & 4 & 103 \\
\hline & $21,4 \%$ & $31,1 \%$ & $7,8 \%$ & $12,6 \%$ & $15,5 \%$ & $7,8 \%$ & $3,9 \%$ & $100,0 \%$ \\
\hline \multirow{2}{*}{ Erkek } & 12 & 27 & 9 & 6 & 13 & 7 & 3 & 77 \\
\hline & $15,6 \%$ & $35,1 \%$ & $11,7 \%$ & $7,8 \%$ & $16,9 \%$ & $9,1 \%$ & $3,9 \%$ & $100,0 \%$ \\
\hline \multirow[t]{2}{*}{ Toplam } & 34 & 59 & 17 & 19 & 29 & 15 & 7 & 180 \\
\hline & $18,9 \%$ & $32,8 \%$ & $9,4 \%$ & $10,6 \%$ & $16,1 \%$ & $8,3 \%$ & $3,9 \%$ & $100,0 \%$ \\
\hline
\end{tabular}

Kadın öğrencilerin \%21,4'ü aile isteğini, \%31,1'i dini doğru ve kapsamlı öğrenmeyi, \%7,8'i daha kolay meslek sahibi olabilmeyi, $\% 12,6^{\prime}$ sı dine hizmet etmeyi, \%15,5'i öğretmen olmayı, \%7,8'i ise mevcut sınav sistemini ilahiyat fakültesini seçme nedeni olarak göstermiş; erkek öğrencilerin ise \%15,6's1 aile isteğini, \%35,1'i dini doğru ve kapsamlı öğrenmeyi, \%11,7'si daha kolay meslek sahibi olabilmeyi, \%7,8'i dine hizmet etmeyi, \%16,9'u öğretmen olmayı ve \%9,1'i mevcut sınav

28 İbrahim Turan, "Din Görevlilerinin Mesleki Yeterlilikleri", Dinbilimleri Akademik Araştırma Dergisi 13/3 (01 Haziran 2013): 49.

29 “Diyanet İşleri Başkanlığ1 2017 Yilı İstatistikleri”, erişim: 21 Mart 2019, https://stratejigelistirme.diyanet.gov.tr/sayfa/57/istatistikler.

30 Emrah Yavuz, "Köy İmamlarının Görev Yaptıkları Yerleşim Biriminin Fiziki ve Sosyokültürel Yapısından Kaynaklanan Problemleri Üzerine Sosyolojik Bir İnceleme Kayseri Pınarbaşı Örneği -", Dini Araştırmalar 18/47 (2016), 175. 
438 I İ. ERPAY / Öğrencilerin İlahiyat Fakültesine Yönelik Görüşleri

sistemini gerekçe olarak göstermiştir. Katılımcıların cinsiyetleri ve ilahiyat fakültesinde eğitim görme nedenleri ilişkilendirildiğinde önemli farklılar olmamakla birlikte ailenin istemesi nedeni ile bu bölümde okuyan kadınların oranının erkek öğrencilere göre daha yüksek olduğu; erkek öğrencilerde ise daha kolay meslek sahibi olma nedeninin kadın öğrencilere göre yüksek olduğu gözlenmektedir. Bu da kadınların ilahiyatı seçmesinde ailelerin daha çok rol aldığını göstermekte, erkeklerin ise daha kolay meslek sahibi olma ilahiyatı seçmede etkin olduğu görülmektedir. Dini daha doğru ve kapsamlı öğrenmek için ilahiyatı tercih eden kadınlara göre erkeklerin oranı daha yüksek iken, dine hizmet konusunda kadınların oranı erkeklere göre önemli derecede yüksek çıkmıştır. Bu durumda erkekler daha çok doğru ve kapsamlı bir dini bilgi edinmek için ilahiyatı tercih ederken, kadınlar için ise doğru ve kapsamlı bir dini bilgi edinmenin yanı sıra (bu oran erkeklerden az olsa da yine de \%31,1 gibi önemli oranda) dine hizmet de önem kazanmaktadır.

5.2 Katılımcıların görüşleri

Tablo 6. Öğrencilere Göre Derslerde Kişisel Yetenekleri Ortaya Çıkarabilme Durumu

\begin{tabular}{|l|c|c|}
\hline \multicolumn{1}{|c|}{$\begin{array}{c}\text { Derslerde kişisel yeteneklerinizi ortaya çıkaracak } \\
\text { çalışmalara fırsat verilmekte midir? }\end{array}$} & $\begin{array}{c}\text { Kişi } \\
\text { Sayısı }\end{array}$ & Yüzde \\
\hline Evet, Bütün Derslerde Fırsat Verilmektedir & 4 & 2,2 \\
\hline Çoğu Derste Fırsat Verilmektedir & 28 & 15,6 \\
\hline Çok Az Derste Fırsat Verilmektedir & 117 & 65,0 \\
\hline Firsat Verilmemektedir Toplam & 31 & 17,2 \\
\hline \multicolumn{2}{|c|}{ "Derslerde kişisel yeteneklerinizi ortaya çıkaracak }
\end{tabular}
çalışmalara firsat verilmekte midir?" sorusu sorulduğunda öğrencilerin çoğunluğu (\%65) kendilerine derslerde çok az fırsat verildiğini, $\% 17,2$ 'sinin ise hiç fırsat verilmediğini belirtmişlerdir. Öğrencilerin sadece \%2,2'si "Evet, tüm derslerde fırsat verilmektedir." cevabını vermiştir. Öğrencilerin büyük bir kısmı derslerde kendilerine fırsat tanınmadığııı, bu nedenle de kişisel kabiliyetlerinin pek de artmadı̆̆ını düşünmektedirler. 
I. ERPAY / The Views of the Students Towards the Faculty of Theology | 439

\section{Tablo 7. Öğrencilere Göre Fakültede Dersler Yürütülürken Dersin İçeriğine Uygun Yöntemler, Teknikler ve Materyallerin Kullanılma}

Durumu

\begin{tabular}{|l|c|c|}
\hline $\begin{array}{c}\text { Fakültede dersler yürüttülürken dersin içeriğine uygun } \\
\text { yöntemler, teknikler ve materyaller kullanılmakta } \\
\text { mıdır? }\end{array}$ & $\begin{array}{c}\text { Kişi } \\
\text { Sayısı }\end{array}$ & Yüzde \\
\hline Evet, Bütün Derslerde Kullanılmaktadır & 2 & 1,1 \\
\hline Çoğu Derste Kullanılmaktadır & 27 & 15,0 \\
\hline Çok Az Derste Kullanılmaktadır & 113 & 62,8 \\
\hline Hayır Kullanılmamaktadır & 38 & 21,1 \\
\hline Toplam & 180 & 100,0 \\
\hline
\end{tabular}

Öğrencilerin \%1,1'i dersler yürütülürken dersin içeriğine uygun yöntemler, teknikler ve materyaller kullanıldığını, \%62,8'i çok az derste kullanıldığını, \%21,'i ise "hayır" kullanılmadığını belirtmiştir.

Adem Güneş'in öğretim elemanları üzerinde yapmış olduğu çalışmada, öğretim elemanlarının her ders kullandığı yöntemler anlatım/takrir ve soru-cevap olmuştur. Öğretim elemanlarının bazen kullanmayı tercih ettiği yöntemler; buldurma (Sokrates yöntemi), örnek olay ve beyin fırtınası olurken, nadiren kullandıkları öğretim yöntemleri; görüş geliştirme, fotoğraf ve resim yorumlama, grup çalışma etkinlikleri, bireysel ve grup tartışma teknikleri, münazara ve eğitsel oyun yöntemidir. Öğretim elemanlarının hiçbir zaman kullanmadı̆̆ yöntemler ise; görüşme yöntemi, gösteri/demonstrasyon, panel-forum, siz olsaydınız ne yapardınız?, çalıştay/workshop, gezi-gözlem, akvaryumdur.

Öğretim elemanlarının materyal kullanımı konusunda her ders kullanılan materyaller; ders kitabı, ders planı ve yazı tahtası olmuştur. Sık sık kullanılan ve tercih edilen ise power point sunulardır. Bazen kullanılan materyalleri ise örnek metinler ve kavram haritaları oluşturmaktadır. Nadiren kullanılan öğretim materyalleri ise fotoğraf/resim/karikatür, video/kısa film, anlam çözümleme tablosu ve çalışma yaprakları olmuştur. Hiçbir zaman kullanılmayan materyaller ise Zaman ve kronoloji materyalleri, tablo materyalleri, dijital/ basılı haritalar, kavram ağları, zihin haritaları, bilgi/kavram kartları, afiş/ poster, kavram karikatürleri, broşür/bülten, 3D görseller/ modeller/ maketler/ kuklalar, bulmacalar oluşturmaktadır.

İlgili çalışmada derslerdeki farklı yöntemin katkısı araştırılmış; "Bir dersin daha iyi anlaşılmasında o derste aktif öğretim yöntemlerinin 
440 । İ. ERPAY / Öğrencilerin İlahiyat Fakültesine Yönelik Görüşleri

kullanılması önemli bir faktördür" değerlendirmesine \%96,8 "katılıyorum" cevabı vermiştir. Diğer taraftan ve materyal kullanımı için; "Derste materyal kullanımı dersin daha iyi anlaşılmasına katkı sağlar" şeklindeki değerlendirmeye \%90,4, "katıllyorum cevabını vermiştir. ${ }^{31}$ Görüldüğü üzere yöntem ve materyal kullanımı öğretim elemanları nazarında büyük öneme sahipken, bu çalışmada öğrenciler öğretim elemanlarını derslerde uygun yöntem ve materyal kullanımı konusunda yetersiz bulmuşlardır. Bunun nedenleri arasında öğretim elemanlarının ders yüklerinin fazlalığı, yeni yöntem ve teknik ihtiyacı hissetmeme, klasik yöntemlerin yeterli olacağı düşüncesi, dersin içeriğinin yeni yöntem ve içeriğe uygun olmama düşüncesi ve fakültenin yeni olması hasebiyle yeterli fiziki ve teknolojik donanıma sahip olmaması gibi etkenler etkili olabilir.

Tablo 8. Öğrencilere Göre Dersleri Yürüten Öğretim Üyesi/Görevlisinin Alanlarında Yeterli Bilgi Birikimine ve Deneyime Sahip Olma Durumu

\begin{tabular}{|l|c|c|}
\hline $\begin{array}{c}\text { Dersleri yürüten öğretim üyesi/görevlisi alanlarında } \\
\text { yeterli bilgi birikimine ve deneyime sahip midir? }\end{array}$ & $\begin{array}{c}\text { Kişi } \\
\text { Sayısı }\end{array}$ & Yüzde \\
\hline Evet, Bütün Öğretim Elemanları Alanında Yeterlidir & 31 & 17,2 \\
\hline Çoğu Öğretim Elemanı Alanında Yeterlidir & 89 & 49,4 \\
\hline Çok Az Ö̆ğretim Elemanı Alanında Yeterlidir & 55 & 30,6 \\
\hline Hayır, Öğretim Elemanları Alanında Yeterli Değildir & 5 & 2,8 \\
\hline Toplam & 180 & 100,0 \\
\hline
\end{tabular}

\%49,4 oranındaki öğrenciye göre dersleri yürüten çoğu öğretim üyesi/görevlisi alanında yeterli iken, \%30,6 oranındaki öğrenciye göre ise çok az öğretim üyesi/görevlisi alanında yeterlidir. \%2,8 oranındaki öğrenciye göre ise öğretim üyesi/görevlisi alanında yeterli değildir. Bu anlamada öğretim elemanları büyük oranda alanında yeterli görülürken, çok az öğretim elemanı alanında yeterli bulunmamaktadır.

31 Adem Güneş, “İlahiyat Fakültesi Öğretim Elemanlarının Lisans Düzeyindeki Derslerde Yöntem ve Materyal Kullanma Durumları", İstanbul Üniversitesi İlahiyat Fakültesi Dergisi 29/1 (15 Haziran 2018): 80-83. 
I. ERPAY / The Views of the Students Towards the Faculty of Theology | 441

Tablo 9. Öğrencilere Göre Sınavların Uygun Yöntem ve Tekniklere

Göre Hazırlanma Durumu

\begin{tabular}{|c|c|c|}
\hline $\begin{array}{c}\text { Sınav soruları uygun yöntem ve tekniklere göre } \\
\text { hazırlanmakta mıdır? }\end{array}$ & $\begin{array}{c}\text { Kişi } \\
\text { Sayısı }\end{array}$ & Yüzde \\
\hline 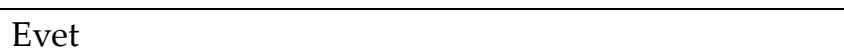 & 53 & 29,4 \\
\hline Hayır & 23 & 12,8 \\
\hline Kismen & 104 & 57,8 \\
\hline Toplam & 180 & 100,0 \\
\hline
\end{tabular}

Öğrencilerin \%29,4'üne göre fakültede sinavlar uygun yöntem ve tekniklerle hazırlanmakta iken, $\% 57,8$ 'ine göre ise kısmen hazırlanmaktadır. \%12,8'ine göre ise fakültede sinavlar uygun yöntem ve tekniklerle hazırlanmamaktadır. Öğrencilerin büyük bir bölümü sınav sorularının kısmen de olsa uygun yöntem ve tekniklere göre hazırlandığını belirtmişlerdir.

Tablo 10. Öğrencilere Göre Öğrenci Başarılarının Objektif Bir Biçimde Değerlendirilme Durumu

\begin{tabular}{|l|c|c|}
\hline \multicolumn{1}{|c|}{$\begin{array}{c}\text { Başarılarınız objektif bir biçimde } \\
\text { değerlendirilmekte midir? }\end{array}$} & Kişi Sayısı & Yüzde \\
\hline Evet & 52 & 28,9 \\
\hline Hayır & 33 & 18,3 \\
\hline Kısmen Toplam & 95 & 52,8 \\
\hline \multicolumn{2}{|c|}{180} & 100,0 \\
\hline
\end{tabular}

Öğrencilerin \%28,9'u "Başarılarınız objektif bir biçimde değerlendirilmekte midir? Sorusuna evet, \%18,3'ü hayır, \%52,8' $\mathrm{i}$ ise kısmen cevabını vermiştir. Öğrenciler, başarılarının değerlendirilmesinin objektifliği konusunda genel kanaat olarak olumlu görmekle beraber, objektif olmadığını söyleyenlerin oranının biraz yüksek olması dikkate alınması gereken bir konu olarak karşımıza çıkmaktadır.

Tablo 11. Öğrencilerin İlahiyattaki Öğretim Ortamına İlişkin Algı

Durumu

\begin{tabular}{|l|c|c|}
\hline \multicolumn{1}{|c|}{ İlahiyattaki öğretim ortamı sizce nasıldır? } & Kişi sayısı & Yüzde \\
\hline Baskıcı ve Zorlayıcı Bir Ortam & 40 & 22,2 \\
\hline Sıkıcı Bir Ortam & 71 & 39,4 \\
\hline $\begin{array}{l}\text { Öğrenme Etkinliklerinin Gerçekleştirildiği Sağlıklı Bir } \\
\text { Ortam }\end{array}$ & 31 & 17,2 \\
\hline Rahat ve Keyifli Bir Ortam & 16 & 8,9 \\
\hline Demokratik ve Özgür Bir Ortam & 22 & 12,2 \\
\hline \multicolumn{1}{|c|}{ Toplam } & 180 & 100,0 \\
\hline
\end{tabular}


442 । İ. ERPAY / Öğrencilerin İlahiyat Fakültesine Yönelik Görüşleri

\%39,4 oranındaki öğrenciye göre ilahiyat fakültesindeki öğretim ortamı sıkıcı bir ortam iken, $\% 8,9$ oranındaki öğrenciye göre ise rahat ve keyifli ortamdır. Ayrıca \%22,2 oranındaki öğrenciye göre baskıcı ve zorlayıcı bir ortam iken, \%12,2 oranındaki öğrenciye göre ise demokratik ve özgür bir ortamdır. Buna göre öğrenciler tarafından ilahiyat öğretim ortamını olumlu bulan; "Öğrenme Etkinliklerinin Gerçekleştirildiği Sağlıklı Bir Ortam", "Rahat ve Keyifli Bir Ortam" ve "Demokratik ve Özgür Bir Ortam" diyenlerin oranı \%38,3'tür. Bunun yanı sıra sıkıc1, baskıcı ve zorlayıcı bir ortam olarak değerlendirenlerin oranı da bir hayli yüksektir. Mezun olduğu okul türü ile ilahiyat öğretim ortamı karşılaştırıldığında (Tablo 12) düz lise ve meslek lisesi ilahiyatı daha baskıcı ve zorlayıcı bulurken, imam hatip lisesi ve açı öğretim daha az baskıcı ve zorlayıcı bulmuştur. Bu durumun nedenleri arasında Öğretim elemanları-öğrenci ve yönetim-öğrenci ilişkisine (Tablo 13) bakıldığında öğrencilerin öğretim elemanları ve yönetime yaklaşımlarında yüksek oranda olumsuzluğa rastlanmadığı görülmektedir. Bunun dışında öğrenciler tarafından ilahiyatın baskıcı ve zorlayıcı olarak algılanmasındaki etkenler dışlanma, söylenti yayma, ideolojik zorbalık vb. doğrudan veya dolaylı akran zorbalığ $1^{32}$ olabileceği gibi ilahiyatın sıkıcı olarak algılanmasında sosyal yaşam alanı yetersizliği, kültürel, sosyal, sanatsal faaliyet eksikliği etkili olmuş olabilir.

32 Akran Zorbalığı hakkında bk. Uğur Ümmiye Özkal, Üniversite Öğrencileri Arasında Zorbalık ve Zorbalı̆̆ın Psikolojik Sorunlarla İlişkisi (Yüksek Lisans Tezi, Ankara Üniversitesi, 2011). 
İ. ERPAY / The Views of the Students Towards the Faculty of Theology | 443

Tablo 12. Mezun Olduğu Okul Türü ile İlahiyat Öğretim Ortamı Alg1

Durumu Arasındaki İlişki

\begin{tabular}{|c|c|c|c|c|c|c|c|}
\hline & \multicolumn{5}{|c|}{ İlahiyat Öğretim Ortamı Sizce Nasıldır? } & \multirow[b]{2}{*}{$\begin{array}{l}\Xi \\
\frac{\pi}{0} \\
\stackrel{0}{0}\end{array}$} \\
\hline & & 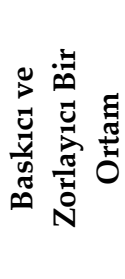 & 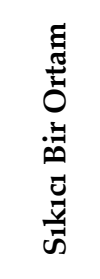 & 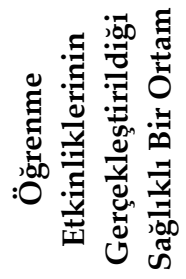 & 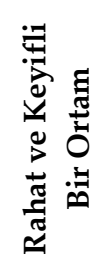 & 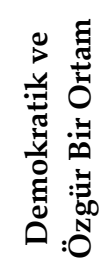 & \\
\hline \multirow{12}{*}{$\begin{array}{c}\text { Mezun } \\
\text { Olduğunu } \\
\text { Okul } \\
\text { Türü? }\end{array}$} & \multirow{3}{*}{$\begin{array}{l}\text { Düz } \\
\text { Lise }\end{array}$} & 15 & 20 & 5 & 4 & 3 & 47 \\
\hline & & $31,9 \%$ & $42,6 \%$ & $10,6 \%$ & $8,5 \%$ & $6,4 \%$ & $100,0 \%$ \\
\hline & & $8,3 \%$ & $11,1 \%$ & $2,8 \%$ & $2,2 \%$ & $1,7 \%$ & $26,1 \%$ \\
\hline & \multirow{3}{*}{$\begin{array}{l}\text { İmam } \\
\text { Hatip } \\
\text { Lisesi }\end{array}$} & 19 & 41 & 23 & 9 & 16 & 108 \\
\hline & & $17,6 \%$ & $38,0 \%$ & $21,3 \%$ & $8,3 \%$ & $14,8 \%$ & $100,0 \%$ \\
\hline & & $10,6 \%$ & $22,8 \%$ & $12,8 \%$ & $5,0 \%$ & $8,9 \%$ & $60,0 \%$ \\
\hline & \multirow{3}{*}{$\begin{array}{c}\text { Meslek } \\
\text { Lisesi }\end{array}$} & 5 & 7 & 1 & 0 & 2 & 15 \\
\hline & & $33,3 \%$ & $46,7 \%$ & $6,7 \%$ &, $0 \%$ & $13,3 \%$ & $100,0 \%$ \\
\hline & & $2,8 \%$ & $3,9 \%$ & $6 \%$ &, $0 \%$ & $1,1 \%$ & $8,3 \%$ \\
\hline & \multirow{3}{*}{$\begin{array}{c}\text { Açık } \\
\text { Öğretim } \\
\text { Lisesi }\end{array}$} & 1 & 3 & 2 & 3 & 1 & 10 \\
\hline & & $10,0 \%$ & $30,0 \%$ & $20,0 \%$ & $30,0 \%$ & $10,0 \%$ & $100,0 \%$ \\
\hline & & ,6\% & $1,7 \%$ & $1,1 \%$ & $1,7 \%$ & ,6\% & $5,6 \%$ \\
\hline \multirow{3}{*}{\multicolumn{2}{|c|}{ Toplam }} & 40 & 71 & 31 & 16 & 22 & 180 \\
\hline & & $22,2 \%$ & $39,4 \%$ & $17,2 \%$ & $8,9 \%$ & $12,2 \%$ & $100,0 \%$ \\
\hline & & $22,2 \%$ & $39,4 \%$ & $17,2 \%$ & $8,9 \%$ & $12,2 \%$ & $100,0 \%$ \\
\hline
\end{tabular}

İlahiyat öğretim ortamını baskıcı ve zorlayıcı bir ortam olarak gören öğrencilerin \%31,9 ‘u düz lise, $\% 17,6$ ’s1 imam hatip lisesi, $\% 33,3$ ’ü meslek lisesi, \%10'u ise açık öğretim lisesi mezunudur.

Öğretim ortamını sıkıcı bir ortam olarak gören öğrencilerin $\% 42,6$ 'sı düz lise, \%38'i imam hatip lisesi, \%46,7'si meslek lisesi, \%30'u ise açı öğretim lisesi mezunudur.

Öğrenme etkinliklerinin gerçekleştirildiği sağlıklı bir ortam olarak gören öğrencilerin \%10'6'sı düz lise, \%21,3'ü imam hatip lisesi, \%6,7'si meslek lisesi, \%20'si açık öğretim lisesi mezunudur. Rahat ve keyifli bir ortam olarak gören öğrencilerin \%8,5'i düz lise, \%8,3'ü imam hatip lisesi, 
444 I İ. ERPAY / Öğrencilerin İlahiyat Fakültesine Yönelik Görüşleri

\%30'u açık öğretisi lisesi mezunu olup; bu oran meslek lisesi öğrencileri içerisinde $\% 0^{\prime}$ dir.

İlahiyat öğretim ortamını demokratik ve özgür bir ortam olarak gören öğrencilerin ise $\% 6,4^{\prime} \ddot{\mathrm{u}}$ düz lise, \%14,8'i imam hatip lisesi, \%13,3' $\ddot{\mathrm{u}}$ meslek lisesi, \%10’u açık öğretim lisesi mezunudur. Değişkenler arasındaki dağılım incelendiğinde; düz lise ile meslek lisesi mezunları ilahiyat ortamını baskıcı ve zorlayıcı bulurken, imam hatip lisesi ile açık öğretim lisesi mezunları çok da baskıcı ve zorlayıcı bulmamaktadır. Ancak düz lise ve meslek lisesi mezunları ilahiyat öğretim ortamını daha sıkıcı bulurken, imam hatip lisesi ve açık öğretim lisesi mezunlarının sıkıcı bulma oranları azalmakla beraber sıkıcı bulmaktadırlar. Açık öğretim lisesi mezunlarından ilahiyatı "Öğrenme Etkinliklerinin Gerçekleştirildiği Sağlıklı Bir Ortam”, "Rahat ve Keyifli Bir Ortam” ve "Demokratik ve Özgür Bir Ortam" olarak bulanların oranı \%60 iken, imam hatip lisesi mezunlarının oranı \%44,4, düz lise mezunlarının oranı $\% 25,5$, meslek lisesi mezunlarının oranı ise \%20'de kalmıştır. Bu da açık öğretim lisesinden gelenlerin ilahiyat öğretim ortamına karşı daha olumlu olduklarını göstermektedir. Bunun nedeni, çoğunluğu Güney Anadolu Bölgesi çevresinden olan öğrenci profili içerisinde açık öğretim lisesinden mezun olanların genelde bölgedeki medreselerde okumuş veya okuyor olmaları, ilahiyat ortamına daha kolay adapte olmalarında etkili olduğu düşünülmektedir.

Tablo 13. Öğrencilerin Öğretim Üyesi/Görevlisi ve Yönetimle Görüşmelerinde Yaşadıkları Duygu Durumu

\begin{tabular}{|l|c|c|}
\hline $\begin{array}{c}\text { Öğretim elemanları ve yönetimle görüşmelerinizde } \\
\text { kendinizi nasıl hissediyorsunuz? }\end{array}$ & $\begin{array}{c}\text { Kişi } \\
\text { Sayısı }\end{array}$ & Yüzde \\
\hline Rahat Hissederim & 136 & 75,6 \\
\hline Stres ve Baskı Hissederim & 14 & 7,8 \\
\hline Çekingen Hissederim & 30 & 16,7 \\
\hline \multicolumn{1}{|c|}{ Toplam } & 180 & 100,0 \\
\hline
\end{tabular}

Öğrenciler öğretim üyesi/görevlisi ve yönetimle olan birebir görüşmelerinde genel olarak kendilerini $(\% 75,6)$ rahat hissetmektedirler. Ancak \%16,7 oranındaki öğrenci görüşmelerde çekingen hissetmekte ve yine $\% 7,8$ oranındaki öğrenci stres ve baskı hissetmektedir. Genel olarak öğrencilerin öğretim elemanları ve yönetim ile ilişkilerinde olumlu bir alg1 mevcut olduğunu söyleyebiliriz. 
I. ERPAY / The Views of the Students Towards the Faculty of Theology | 445

Tablo 14. İlahiyat Alan Derslerinin Güncel Sorunları Çözme Durumu

\begin{tabular}{|c|c|c|}
\hline $\begin{array}{l}\text { İlahiyattaki dersler güncel sorunları çözmeye } \\
\text { dönük müdür? }\end{array}$ & Kişi Sayısı & Yüzde \\
\hline Evet & 16 & 8,9 \\
\hline Kısmen & 117 & 65,0 \\
\hline Hayır & 47 & 26,1 \\
\hline Toplam & 180 & 100,0 \\
\hline
\end{tabular}

$\% 8,9$ oranındaki öğrenciye göre ilahiyat dersleri dinle ilgili güncel sorunları çözmeye dönük iken, \%65 oranındaki öğrenciye göre kısmen çözmeye yönelik olup, \%26,1 oranındaki öğrenciye göre ise böyle bir durum söz konusu olmayıp ilahiyat alan dersleri, dinle ilgili güncel sorunları çözmeye yönelik değildir. Eğitimde kalitenin artması için konular hayatın gerçeklerine uygun olarak güncelleştirilmelidir. ${ }^{33} \mathrm{Bu}$ bakımdan ele alındığında öğrencilerin çok azı ilahiyat derslerinin güncel sorunlara dönük olduğunu söylerken, büyük bir kısmı derslerin güncel sorunları kısmen ele aldığını belirtmiştir. Bu soruya hayır diyenlerin oranı da azımsanmayacak derecededir.

Tablo 15. Öğrencilerin İlahiyat Fakültesinde Aldığı Eğitimi Yeterli Görme Durumu

\begin{tabular}{|c|c|c|}
\hline $\begin{array}{c}\text { İlahiyat Fakültesinde aldığınız eğitimi } \\
\text { yeterli görüyor musunuz? }\end{array}$ & Kişi Sayısı & Yüzde \\
\hline Evet & 9 & 5,0 \\
\hline Kismen & 93 & 51,7 \\
\hline Hayır & 78 & 43,3 \\
\hline Toplam & 180 & 100,0 \\
\hline
\end{tabular}

Öğrencilerin \%5'i (9 kişi) ilahiyat fakültesinde aldıkları eğitimleri yeterli görmekte iken, \%51,7'si (93 kişi) kısmen yeterli görmekte ve \%43,3'ü (78 kişi) oranına sahip öğrenciler ise aldıkları eğitimleri yeterli görmemektedir. Dicle üniversitesi örneğinde öğrencilerin \%1,3'ü verilen eğitimin tamamen yeterli olduğunu, \%72,2'si eğitimin yetersizliğini, $\% 26,5$ 'i verilen eğitimin kısmen yeterli olduğunu dile getirmiştir. ${ }^{34} \mathrm{Bu}$ veriler 1şığında oranlar farklı olsa da öğrenciler genel olarak ilahiyatta verilen dersleri yeterli görmemektedir.

33 Koç, “İâhiyat Fakültesi (İlâhiyat Lisans Programı) Öğrencilerinin Sorunları ve Beklentileri", 61.

34 Özenç, “Son Sınıf Öğrencilerine Göre Beklentileri Karşılama ve Mesleki Hayata Hazırlamada İlahiyat Fakültelerinde Eğitim (Dicle Üniversitesi Örneği)", 11-12. 
446 | İ. ERPAY / Öğrencilerin İlahiyat Fakültesine Yönelik Görüşleri

Tablo 16. Öğrencilerin İlahiyatı Seçme Nedenleri ile İlahiyatta Aldıkları Eğitimi Yeterli Bulma Durumu Arasındaki İlişki

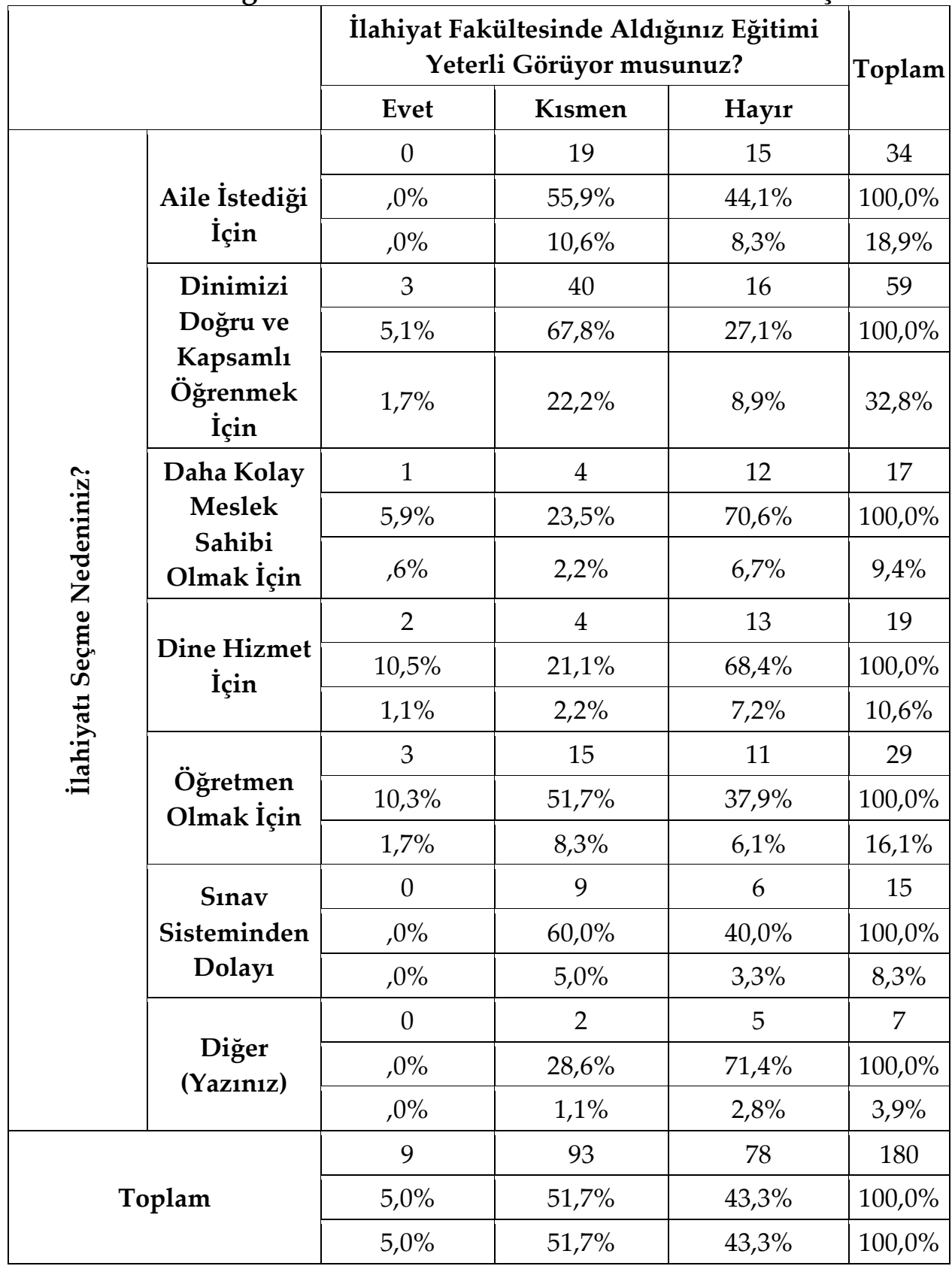


İlahiyatı seçme nedeni olarak aile isteğini gösteren öğrenciler ile sınav sisteminden dolayı bu bölümü seçen öğrenciler ayrıca diğer sebeplerle bu bölümde okumayı tercih eden öğrenciler içerisinde $\% 0$ oranında öğrenci aldıkları eğitimi yeterli görmüşlerdir. Daha kolay meslek sahibi olmak için gelen öğrencilerin ise $\% 5,9^{\prime} u$ öğretmen olmak için gelenlerin $\% 10,3^{\prime}$ ü, dine hizmet etmek için gelenlerin $\% 10,5^{\prime} i$ ve son olarak dini doğru ve kapsamlı öğrenmek için gelen öğrencilerin $\% 5,9^{\prime} u$ aldığı eğitimi yeterli görmüştür.

İlahiyatı seçme nedeni olarak aile isteğini gösteren öğrencilerin $\% 55,9^{\prime} \mathrm{u}$, sinav sisteminden dolayı bu bölümü okuyan öğrencilerin $\% 60^{\prime} 1$, öğretmen olmak için gelenlerin \%51,7'si, diğer sebeplerle gelen öğrencilerin \%28,6's1, dine hizmet etmek için gelenlerin $\% 21,1^{\prime} \mathrm{i}$, daha kolay meslek sahibi olmak için gelenlerin $\% 23,5$ i ve dini doğru ve kapsamlı öğrenmek için gelen öğrencilerin \%67,8'i aldığı eğitimi kısmen yeterli görmektedir.

Yine aile isteğini sebep olarak gösteren öğrencilerin $\% 44,1^{\prime} i$, dini doğru ve kapsamlı bir şekilde öğrenmeyi gerekçe olarak gösteren öğrencilerin \%27,1'i, daha kolay meslek sahibi olmak için tercih eden öğrencilerin $\% 70^{\prime} \mathrm{i}$, dine hizmet etmek amaciyla gelen öğrencilerin $\% 68,4^{\prime} \ddot{u}$, öğretmen olmak için gelenlerin $\% 37,9^{\prime}$ u, sınav sistemini gerekçe olarak gösteren öğrencilerin $\% 40^{\prime} 1$ ve son olarak diğer sebeplerden dolayı bu bölümde okumayı tercih eden öğrencilerin \%71,4'ü ilahiyat fakültesi eğitim sürecinde aldıkları eğitimleri yetersiz görmektedirler. Bu iki değişken arasındaki ilişki incelendiğinde; aile isteği ve sınav sisteminden dolayı ilahiyatı tercih edenler aldıkları eğitimi tamamen yeterli görmezken, dinimizi doğru ve kapsamlı öğrenmek ve öğretmen olmak için tercih edenlerin büyük oranı kısmen yeterli görmektedirler. Daha kolay meslek sahibi olmak isteyenler, dine hizmet için tercih edenler ve diğerlerinin büyük bir çoğunluğu ilahiyatta aldıkları eğitimi yeterli görmemektedirler. Aldıkları eğitimi yeterli görmeyenler arasında en az oranı oluşturanlardan birisi öğretmen olmak isteyenler olmuştur ki, dine hizmet için tercih edenlerin büyük oranda eğitimi yetersiz görmeleri düşünüldügünde ve son yillarda ilahiyatlarda başlayan formasyon dersleri ile beraber ilahiyatta yapılan eğitimin daha çok öğretmen olmak isteyenlere hitap ettiği düşünülebilir. Dolayısıyla ilahiyat fakültesinde verilen eğitim öğretmen olacak öğrenciler tarafından kısmen daha yeterli bulunmaktadır. 
448 | İ. ERPAY / Öğrencilerin İlahiyat Fakültesine Yönelik Görüşleri

Ki Kare Testi

\begin{tabular}{|c|c|c|c|}
\hline & Value & df & Asymp. Sig. (2-sided) \\
\hline Pearson Chi-Square & $22,096^{\mathrm{a}}$ & 12 &, 009 \\
\hline
\end{tabular}

Pearson Ki-Kare ,009<0,05' ten küçük olduğu için "öğrencilerin ilahiyatı seçme nedenleri ile ilahiyatta aldıkrı eğitimi yeterli bulma" değişkenleri arasında anlamlı bir farklılık olduğu görülmektedir.

\section{Tablo 17. Öğrencilerin İlahiyat Fakültesinde Aldığı Eğitimi Yeterli} Görmeme Nedenleri

\begin{tabular}{|l|c|c|}
\hline $\begin{array}{c}\text { Illahiyat Fakültesinde aldığınız eğitimi neden yeterli } \\
\text { görmüyorsunuz? }\end{array}$ & Kişi Sayısı & Yüzde \\
\hline Ders Hocalarının Formasyon Eksikliği & 31 & 17,2 \\
\hline Ders Hocalarının Alan Bilgisi Eksikliği & 16 & 8,9 \\
\hline Fakültenin Fiziki Şartları & 7 & 3,9 \\
\hline Müfredattaki Ders Saat ve Kredilerinin Yetersizliği & 20 & 11,1 \\
\hline Müfredattaki Ders Saat Ve Kredilerinin Fazla Olması & 18 & 10,0 \\
\hline Diğer Toplam & 15 & 8,3 \\
\hline \multicolumn{1}{|c|}{ İlahiyat fakültesinde verilen eğitimleri yeterli görmeyen }
\end{tabular}

öğrencilere verilen eğitimleri neden yeterli görmedikleri sorulduğunda öğrencilerin \%17,2'si ders hocalarının formasyon eksikliğini, \%8,9'u ders hocalarının alan bilgisi eksikliğini, \%3,9'u fakültenin fiziki şartlarını, $\% 11,1^{\prime} i$ müfredattaki ders saatlerinin ve kredilerinin yetersizliğini, \%10'u ise müfredattaki ders saatlerinin ve kredilerinin fazla olmasinı neden olarak göstermişlerdir. \%8,3 oranındaki öğrenci ise diğer başlık altında; "derslerde belli başlı kitaplara bağh kalındiğı, yöntem, teknik ve uygulamanın eksikliği, teorik bilgilerin fazlalığl, derslerde bilinenlerin tekrarl, öğrencilerin derse olan katılımlarının yetersizliği, sınav odakl ders işlenmesi, her şeyden biraz öğretilip hiçbir şeyin tam olarak öğretilmediği, derslerin araştırmaya sevk etmediği, bazı hocaların dersleri aktarmada başarılı olamamaları ve dersi yeterince önemsememeleri sonucu öğrencilerin ilgilerinin kaybolması, güncel konular üzerine yeteri kadar fikir ve tartışmaların olmaması, öğrenci olarak kendilerinden kaynaklı, öğrenciler olarak bilgi sahibi olmak için ders dışı fazla bir çaba sarf etmedikleri" gibi birçok neden göstermişlerdir.

Öğrenciler ders hocalarını alan bilgisinde yeterli bulurken, formasyon konusunda yeterli bulmamaktadır. Ders hocalarının formasyon eksikliği diğer çalışmalarla da örtüşmektedir. Dolayısıyla 
ilahiyatlarda ders hocalarının formasyon eksikliği problem olarak karşımıza çıkmaktadır.

Tablo 18. Öğrencilere Göre İlahiyat Fakültesinde Alınan Eğitimin Kendilerinin ve Toplumun Dinî İhtiyaçlarına Cevap Verme Durumu

\begin{tabular}{|c|c|c|}
\hline $\begin{array}{c}\text { İlahiyat Fakültesinde aldığınız eğitimin sizin ve } \\
\text { toplumun dinî ihtiyaçlarına cevap vereceğini } \\
\text { düşünüyor musunuz? }\end{array}$ & $\begin{array}{c}\text { Kişi } \\
\text { sayısı }\end{array}$ & $\begin{array}{c}\text { Yüzd } \\
\text { e }\end{array}$ \\
\hline Evet & 36 & 20,0 \\
\hline Hayır & 21 & 11,7 \\
\hline Kismen & 123 & 68,3 \\
\hline Toplam & 180 & 100,0 \\
\hline
\end{tabular}

İlahiyat fakültesinde alınan eğitimlerin öğrencilerin kendilerine ve toplumun dini ihtiyaçlarına cevap vereceği beklentisi incelendiğinde öğrencilerin \%20'sine göre evet vereceği, \%68,3'üne göre kısmen vereceği ve \%11,7'sine göre ise vermeyeceği doğrultusundadır. Buna göre verilen eğitimler büyük oranda toplumun ve bireyin ihtiyaçlarına cevap verebilecek düzeyde diyebiliriz.

Tablo 19. İlahiyat Fakültesinde Alınan Eğitimin Okullarda Din Dersini Vermede Yeterlilik Durumu

\begin{tabular}{|c|c|c|}
\hline \begin{tabular}{|c}
$\begin{array}{c}\text { İlahiyat Fakültesinde aldığınız eğitimin okullardaki din } \\
\text { derslerini vermede yeterli olacağını düşünüyor } \\
\text { musunuz? }\end{array}$ \\
\end{tabular} & $\begin{array}{l}\text { Kişi } \\
\text { sayıs1 }\end{array}$ & Yüzde \\
\hline Evet & 42 & 23,3 \\
\hline Hayır & 25 & 13,9 \\
\hline Kismen & 113 & 62,8 \\
\hline Toplam & 180 & 100,0 \\
\hline
\end{tabular}

Araştırma kapsamındaki öğrencilerin \%23,3'üne göre fakültede alınan derslerin, okullarda din dersi vermede yeterli olduğu yönünde iken; \%13,9 oranındaki öğrenciye göre ise yeterli görülmemektedir. $\% 62,8$ oranındaki öğrenciye göre de fakültede alınan dersler okullarda din eğitimi vermek için kısmen yeterlidir. Oranlara bakıldığında ilahiyatta verilen eğitimin öğretmenlik için yeterli olduğu söylenebilir. 
450 | İ. ERPAY / Öğrencilerin İlahiyat Fakültesine Yönelik Görüşleri

Tablo 20. Öğrencilerin İlahiyatı Seçme Nedenleri ile Aldıkları Eğitimin Din Dersini Vermede Yeterli Olma Durumu Arasındaki İlişki

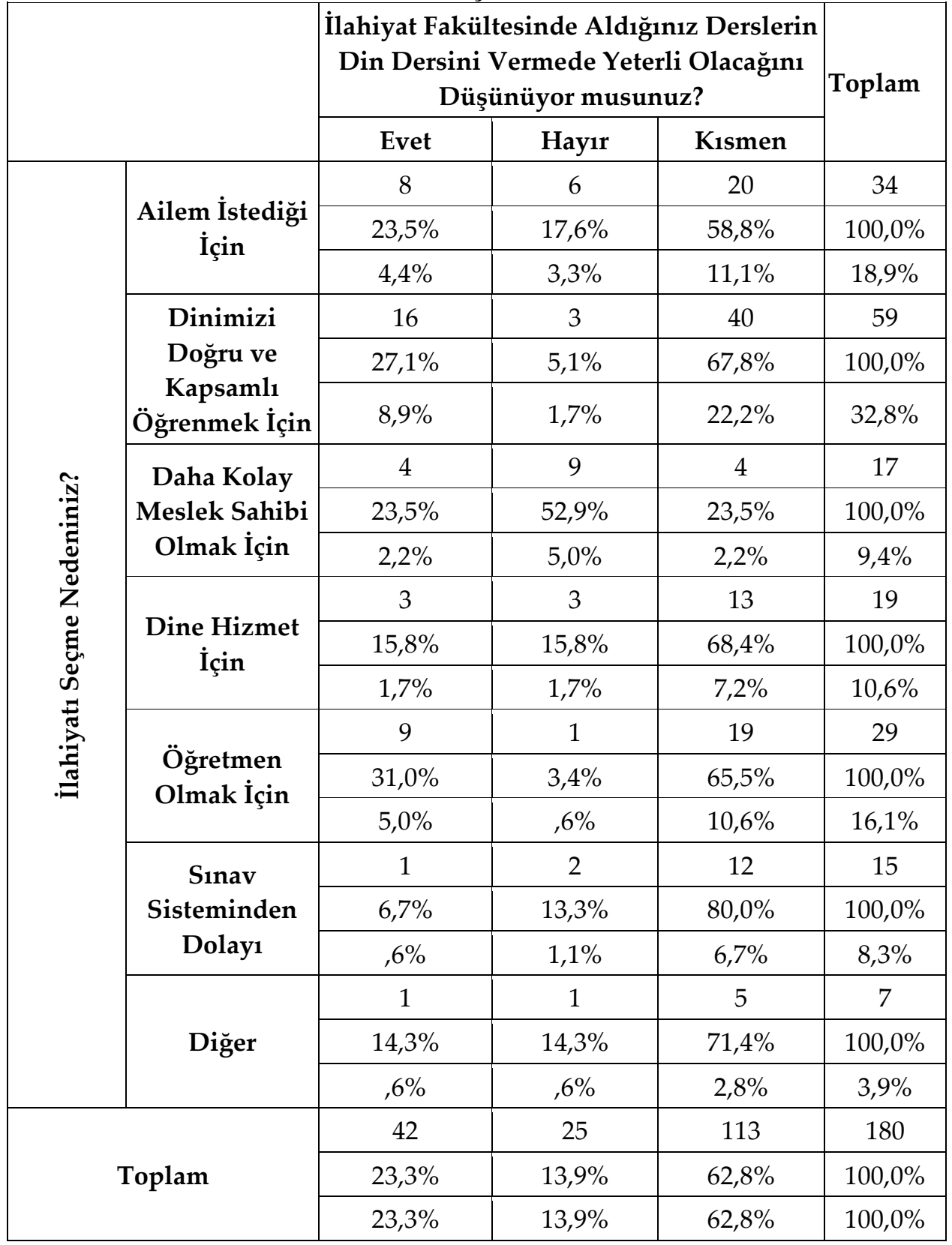


İlahiyat fakültesini tercih etme nedeni olarak aile isteğini gerekçe gösteren öğrencilerin \%23,5'i ilahiyat fakültesinde aldığ1 derslerin din dersi vermede yeterli olduğunu, $\% 58,8$ 'i k1smen yeterli olduğunu, $\% 17,6^{\prime}$ sı ise yeterli olmadığını düşünmektedir. Dini doğru ve kapsamlı öğrenmek için gelen öğrencilerin \%27,1'i ilahiyat fakültesinde aldığ 1 derslerin din dersi vermede yeterli olduğunu, \%67,8'i kısmen yeterli olduğunu, \%5,1'i ise yeterli olmadığını düşünmektedir. Daha kolay meslek sahibi olmak için gelenlerin \%23,5'i ilahiyat fakültesinde aldığ1 derslerin din dersi verme de yeterli olduğunu, \%52,9' $\mathbf{u}^{\prime}$ si yetersiz olduğunu, \%23,5'i ise kısmen yeterli olduğunu düşünmektedir. Dine hizmet amacı ile ilahiyat fakültesinde okumayı tercih eden öğrencilerin $\% 15,8^{\prime} i$ aldığ1 eğitimin din dersi vermede yeterli olduğunu düşünüyorken; \%15,8'i yeterli olmadığını düşünmektedir. Ayrıca $\% 68,4^{\prime}$ ü ise kısmen yeterli olduğunu düşünmektedir. Öğretmen olmak için tercih eden öğrencilerin \%31'i ilahiyat fakültesinde aldığ 1 derslerin din dersi vermede yeterli olduğunu, \%3,4'ü yetersiz olduğunu, \%65,5'i kısmen yeterli olduğunu düşünmektedir. Sınav sisteminden dolayı İlahiyat fakültesinde okumayı tercih eden öğrencilerin \%6,7'si yeterli, \%80'i kısmen yeterli, \%13,3'ü yetersiz gördügüüü belirtmişlerdir. Diğer sebeplerle gelen öğrencilerin ise $\% 71,4^{\prime} \ddot{u}$ ilahiyat fakültesinde aldıkları eğitimin din dersi vermede kısmen yeterli, \%14,3'ü yetersiz olduğunu düşünmektedir.

Değişkenler arasındaki anlamlılık ilişkisi incelendiğinde; dini doğru ve kapsamlı öğrenmek, dine hizmet ve öğretmen olmak için ilahiyatı tercih edenlerin büyük bir kısmı ilahiyatta verilen eğitimin din dersi vermeye yeterli veya kısman yeterli olduğunu belirtirken, daha kolay meslek sahibi olmak için ilahiyatı tercih edenlerin ilahiyatta verilen eğitimin din dersi vermeye yeterli olmadığını belirtenlerin oranı yüksektir. Bu da öğrencilerin ilahiyatı tercih amaçları ile ilahiyattan beklentileri arasındaki ilişkinin doğru orantılı olduğunu göstermektedir.

Ki Kare Testi

\begin{tabular}{|c|c|c|c|}
\hline & Value & df & Asymp. Sig. (2-sided) \\
\hline Pearson Chi-Square & $33,599^{a}$ & 12 &, 001 \\
\hline
\end{tabular}

Pearson Ki-Kare ,001<0,05' ten küçük olduğu için “öğrencilerin ilahiyatı seçme nedenleri ile aldıkları eğitimin din dersi vermeye yeterli olacağına ilişskin düşünceleri" değişkenleri arasında anlamlı bir farklılık ilişkisi söz konusudur. Yani öğrencilerin ilahiyat fakültesinde okumayı 
452 । İ. ERPAY / Öğrencilerin İlahiyat Fakültesine Yönelik Görüşleri

tercih etme nedenleri ile aldıkları derslerle din eğitimi vermede yetkinlik düşünceleri farklılık göstermektedir.

Tablo 21. İlahiyat Fakültesinde Felsefe Derslerinin Gerekli ve Yararlı Olma Durumu

\begin{tabular}{|c|c|c|}
\hline $\begin{array}{l}\text { İlahiyatta felsefe derslerini gerekli ve yararlı } \\
\text { buluyor musunuz? }\end{array}$ & $\begin{array}{c}\text { Kişi } \\
\text { sayısi }\end{array}$ & Yüzde \\
\hline Evet & 106 & 58,9 \\
\hline Hayır & 27 & 15,0 \\
\hline Kismen & 47 & 26,1 \\
\hline Toplam & 180 & 100,0 \\
\hline
\end{tabular}

Araştırma sonucu elde edilen bulgulara göre ilahiyat fakültesinde felsefe dersinin verilmesi; $\% 58,9$ oranındaki öğrenci tarafından yararlı ve gerekli görülmekte olup, $\% 26,1$ oranındaki öğrenci tarafından ise gerekli ve yararlı görülmemektedir. \%26,1 oranındaki öğrenciye göre ise kısmen gerekli ve yararlı görülmektedir. Yapılan çalışmalarda Felsefe ve Din Bilimleri alanındaki derslerin dine bakış, dinî anlayış ve yorumlamalar üzerinde etkili olduğu öğrenciler tarafından kabul edilmektedir. ${ }^{35}$ Felsefe gurubu dersler söz konusu olduğunda öğrencilerin çoğunluğunun felsefeyi, dini daha iyi anlamaya katkı sağlayan bir etkinlik olarak görmekte ve kazandıkları felsefî bakış açısının, dini bilgilerini tutarlı kılma ve sistematik bir hale getirme hususunda yararlı olduğunu düşünmektedir. ${ }^{36}$ Çalışmada (\%85) büyük oranında öğrenci felsefe derslerini gerekli ve yararlı bulurken kısmi orandaki (\%15) öğrenci ise gerekli ve yararlı görmemektedir.

35 Ayşe Taşkıran, “İlahiyat Fakültesi Müfredatında Felsefe ve Din Bilimleri Bölümü Derslerinin Yeri ve Fonksiyonlarına Dair Bir Araştırma (İlahiyat Fakültesi Öğrencileri Örneği)", Kahramanmaraş Sütçü İmam Üniversitesi İlahiyat Fakültesi Dergisi 22 (02 Aralık 2013): 253.

36 Fatih Toktaş - H. Yusuf Acuner, "İlahiyat Fakültelerinde Felsefe Dersleri Ondokuz Mayıs Üniversitesi İlahiyat Fakültesi Örneği", Ondokuz Mayıs Üniversitesi İlahiyat Fakültesi Dergisi 17/17 (2004): 166-167. 
I. ERPAY / The Views of the Students Towards the Faculty of Theology | 453

Tablo 22. İlahiyat Fakültesinde Formasyon Derslerinin Gerekli ve Yararlı Bulunma Durumu

\begin{tabular}{|c|c|c|}
\hline \begin{tabular}{|c|} 
İlahiyatta formasyon derslerini gerekli ve yararlı \\
buluyor musunuz?
\end{tabular} & Kişi sayısı & Yüzde \\
\hline Evet & 145 & 80,6 \\
\hline Hayır & 5 & 2,8 \\
\hline Kismen & 30 & 16,7 \\
\hline Toplam & 180 & 100,0 \\
\hline
\end{tabular}

Öğrencilerin \%80,6'sına göre ilahiyat fakültesinde formasyon dersleri gerekli ve yararlı, \%16,7'sine göre k1smen gerekli ve yararlı iken; $\% 2,8$ 'ine göre ise formasyon dersleri gerekli ve yararlı değildir. 1998 yılında ilahiyatların iki ayrı programa ayrılması ve din eğitimi dışında ilahiyat lisans programlarından eğitim derslerinin kaldırılması ilahiyat mezunların istihdam alanlarını daraltmıştır. 2010-2011 öğretim yılından itibaren 1 ve 2 . sinıf derslerinin not ortalaması 2,5 ve üzeri olan öğrenciler ile mezun durumda olan ilahiyat fakültesi öğrencilerinden diploma notu 2,5 ve üzeri olan öğrenciler Pedagojik Formasyon Sertifikası almaya başlamışlardır. ${ }^{37}$ Ancak ilahiyat lisans eğitiminden ayrı ve kısa süreli programla verilmeye çalışılan pedagojik formasyon programının öğretmenlik mesleğini tanıma ve öğretmenlik becerisi kazanma açısından yetersiz bulunduğu tespit edilmiştir. ${ }^{38}$ YÖK'ün karariyla 25 kredilik pedagojik formasyon dersleri ilahiyat lisans programı içine dahil edilmiştir. ${ }^{39}$ YÖK'ün bu kararının öğrenciler tarafından desteklendiği, çalışmada öğrencilerin formasyon derslerini ilahiyat içerisinde gerekli görme ve yararlı bulma oranı $(\% 97,2)$ ile ortaya koymuştur.

37 Bayraramali Naziroğlu - Mevlüt Kaya, “İlahiyat Fakültelerinde Pedagojik Formasyon Derslerinin Tarihi Gelişimi", Modern Dönemde İlahiyat Eğitimi, Müfredatı ve Yöntem Tartışmaları (Uluslararası Katılımlı Çalıştay), 2010, 137.

38 Ayşegül Gün, "Öğrencilerin Mesleki Yeterlilik Algıları ve Pedagojik Formasyon Programına İlişkin Görüşleri: Amasya Üniversitesi Örneği", Amasya Üniversitesi İlahiyat Fakültesi Dergisi 4/8 (30 Haziran 2017): 163.

39 "YÖK Başkanlığı, İlahiyat Formasyon Programları, 23.06.2017 tarihli 75850160104.01.07.01-434446 say1lı yazısı", 2017. 
454 | İ. ERPAY / Öğrencilerin İlahiyat Fakültesine Yönelik Görüşleri

Tablo 23. İlahiyat Fakültesi Eğitim Sürecinde En Çok Zorlanılan Dersler

\begin{tabular}{|c|c|c|}
\hline $\begin{array}{c}\text { İlahiyat Fakültesi Eğitim Sürecinde En Çok Zorlandığınız } \\
\text { Dersler Hangileridir? }\end{array}$ & $\begin{array}{c}\text { Kişi } \\
\text { sayısi }\end{array}$ & Yüzde \\
\hline $\begin{array}{l}\text { Temel İslam Bilimleri (Arapça, Kuran, İslam Hukuku, Hadis, } \\
\text { Kelam, İslam Mezhepleri tarihi) }\end{array}$ & 95 & 52,8 \\
\hline İslam Tarihi ve Sanatları & 8 & 4,4 \\
\hline $\begin{array}{l}\text { Felsefe ve Din Bilimleri (Felsefe, Mantık, Din Sosyolojisi, Din } \\
\text { Psikolojisi, Din Eğitimi, Dinler Tarihi) }\end{array}$ & 37 & 20,6 \\
\hline Pedagojik Formasyon Dersleri & 25 & 13,9 \\
\hline Diğer (İngilizce, Türk Dili, İnkılap Tarihi) Dersler & 13 & 7,2 \\
\hline Hiçbiri & 2 & 1,1 \\
\hline Toplam & 180 & 100,0 \\
\hline
\end{tabular}

Araştırma kapsamındaki öğrencilerin çoğunluğu $(\% 52,8)$ ilahiyat fakültesi eğitim sürecinde en fazla Temel İslami Bilim derslerinde zorlanmakta olup, bunu ise \%20,6 oraniyla Felsefe ve Din Bilimleri dersi takip etmektedir. Ayrıca \%13,9 oranındaki öğrenci Pedagojik Formasyon, $\% 4,4$ oranındaki öğrenci İslam Tarihi ve Sanatları derslerinde zorlandıklarını belirtmişlerdir. \%1,1 oranına sahip öğrencilerin ise zorlandıkları herhangi bir ders bulunmamaktadır. 
İ. ERPAY / The Views of the Students Towards the Faculty of Theology | 455

Tablo 24. Öğrencilerin Mezun Olduğu Okul Türü ile Zorlandığı Derler Arasındaki İlişki

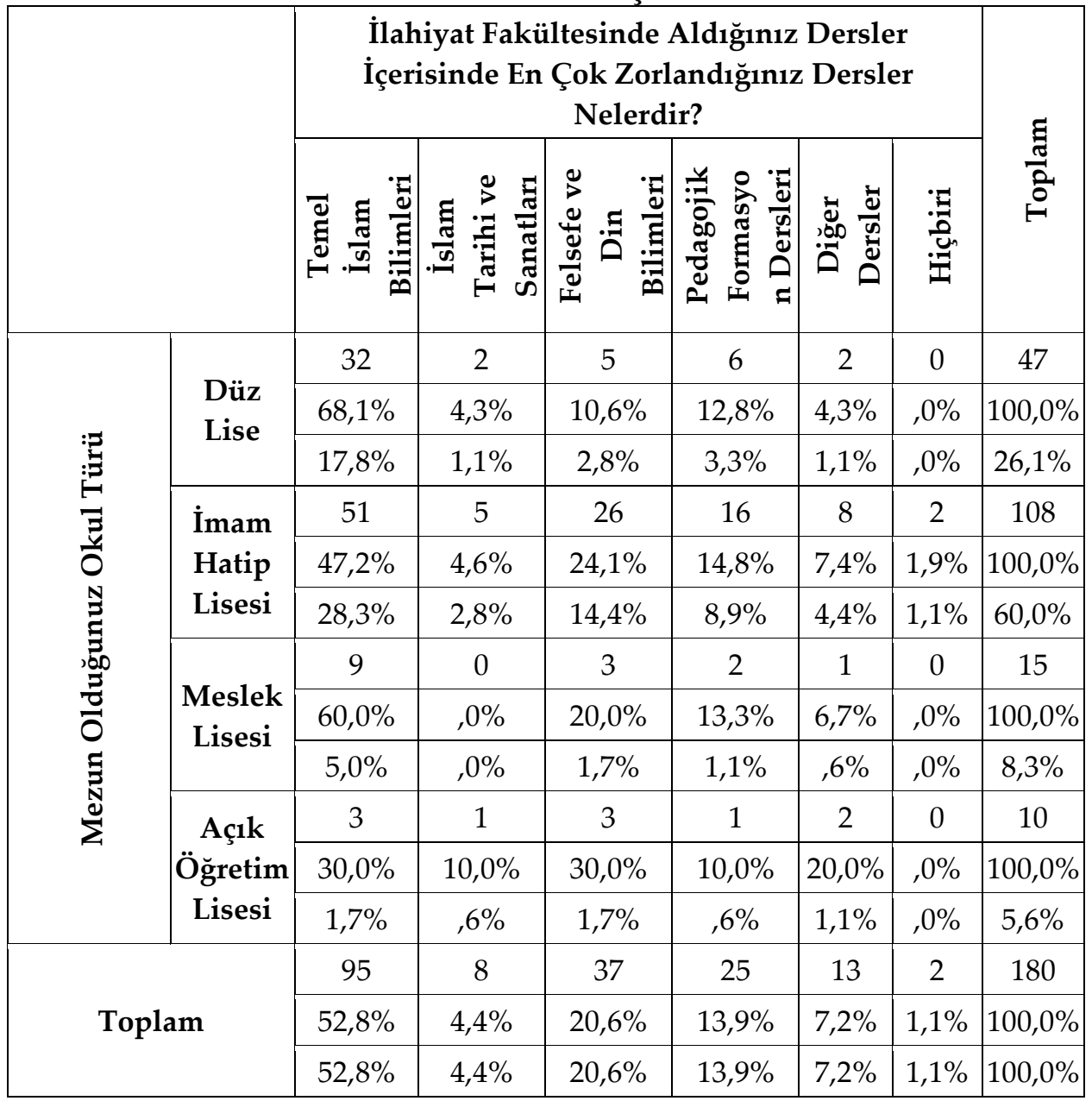

Düz lise mezunu öğrencilerin \%68,1'i, imam hatip lisesi mezunu öğrencilerin $\% 47,2$ 'si, meslek lisesi mezunu öğrencilerin $\% 60^{\prime} 1$, aç1k öğretim mezunu öğrencilerin ise \%30'u ilahiyat fakültesinde eğitim sürecinde en çok zorlandıkları dersin "Temel İslam Bilimleri Dersi" olduğunu belirtmişlerdir. Buna karşın en az zorlanılan ders olarak da düz lise mezunu öğrencilerin \%4,3'ü “İslam Tarihi ve Sanatları Dersini ve diğer", imam hatip lisesi mezunu öğrencilerin \%4,6's1 da "İslam Tarihi ve Sanatları Dersini", aynı şekilde açık öğretim lisesi mezunu öğrencilerin ise $\% 10$ 'u "İslam Tarihi ve Sanatlarn Dersini ve Pedagojik Formasyon Dersini" göstermişlerdir. Meslek lisesi mezunu öğrencilerin ise hiçbirinin "İslam 
456 | İ. ERPAY / Öğrencilerin İlahiyat Fakültesine Yönelik Görüşleri

Tarihi ve Sanatları Dersinde" zorlanmadığı görülmektedir. Bu değişkenler arasındaki ilişki durumu incelendiğinde ise; düz lise mezunları ve meslek lisesi mezunları Temel İslam Bilimleri derslerinden daha çok zorlanırken, imam hatip lisesi ve açık öğretim lisesi mezunları daha az zorlanmaktadırlar. Buna karşın Felsefe ve Din Bilimleri derslerinde düz lise mezunları ve meslek lisesi mezunları daha az zorlanırken, imam hatip lisesi ve açı öğretim lisesi mezunları daha çok zorlanmaktadır. Ayrıca açık öğretim lisesi mezunlarının İngilizce, Türk Dili ve İnkılap Tarihi derslerinden de diğer lise mezunlarına göre daha çok zorlandıkları görülmektedir. Açık öğretim lisesinden mezun olanların Felsefe ve Din Bilimleri ile diğer (İngilizce vb.) derslerden daha çok zorlanma nedenleri ile Temel İslam Bilimleri derslerinde zorlanmama nedenleri düşünüldüğünde, açık öğretim lisesinden mezun olanların yaşamakta olduğu bölgenin daha çok Güneydoğu Anadolu Bölgesi olması ve buralarda bulunan yaygın din eğitimi kurumları gösterilebilir. Açık öğretim mezunu öğrencilerin büyük bir kısmı bölgede bulunan muhtemel medreselerde din eğitimi almakta veya almış bulunmaktadır. Dolayısıyla açık öğretimden ilahiyat fakültesine gelen öğrenciler için Temel İslam Bilimleri dersleri zor gelmezken, hiç görmedikleri Felsefe ve Din Bilimleri dersleri ile diğer (İngilizce vb.) derslerin zor geldiği görülmektedir.

Dicle Üniversitesi İlahiyat Fakültesi öğrencilerine yapılmış olan bir anket çalışmasında öğrencilere "En çok hangi dersten zorlandınız ve ilgi duymadınız? Üç tanesinin ismini yazar mısınız?" sorusuna öğrenciler, ilk sırada Temel İslam Bilimleri dersi içerinde yer alan Arapça dersini (\%52) göstermişlerdir. ${ }^{40}$

\section{Tablo 25. Öğrencilerin Arapça Öğretim Metodunu Doğru ve Yeterli} Bulma Durumu

\begin{tabular}{|c|c|c|}
\hline $\begin{array}{l}\text { Arapça öğretim metodunu doğru ve yeterli } \\
\text { buluyor musunuz? }\end{array}$ & Kişi sayısı & Yüzde \\
\hline Evet & 17 & 9,4 \\
\hline Hayır & 91 & 50,6 \\
\hline Kismen & 72 & 40,0 \\
\hline Toplam & 180 & 100,0 \\
\hline
\end{tabular}

40 Okumuş, “İlahiyat Fakültesi Öğrencilerinin Problemleri -Dicle Üniversitesi Örneği-”, 77. 
İ. ERPAY / The Views of the Students Towards the Faculty of Theology I 457

Öğrencilerin \%50,6'sına göre Arapça dersi öğretim metodu doğru ve yeterli değilken; \%40'ına göre ise kısmen yeterlidir. Arapça dersi öğretim metodunu tamamen doğru ve yeterli bulanların oranı ise $\% 9,4^{\prime}$ te kalmıştır. Dicle İlahiyat Fakültesi örneğinde ise öğrencilerin \%77'si Arapça öğretim metodunun doğru ve yeterli olmadığını, \%20,8'i kısmen, $\% 2,2$ 'si tamamen yeterli olduğunu belirtmişlerdir. ${ }^{41}$ Yapılan çalışmalarda Arapçadan öğrencilerin soğutulduğu, Arapça öğretimi ile ilgili sorunların olduğu, Arapça öğretim yönteminin öğrenciler tarafından pek beğenilmediğ $i^{42}$ yönünde öğrenci görüşleri mevcuttur. Erciyes Üniversitesi İlahiyat Fakültesinde yapılmış olan çalışmada Arapça dersinden zorlandıklarını belirtenlerin oranı $\% 74,3$ olmuştur. ${ }^{43}$

Tablo 26. Arapça Öğretim Metodunu Yeterli Bulmayanlar ile Kısmen Yeterli Bulanların Nedenleri

\begin{tabular}{|l|c|c|}
\hline \multicolumn{1}{|c|}{$\begin{array}{c}\text { Cevabınız kısmen veya hayır ise bunun nedeni } \\
\text { nedir? }\end{array}$} & Kişi Sayısı & Yüzde \\
\hline Ders anlatım yöntem ve teknikleri & 88 & 48,9 \\
\hline Hoca öğrenci arasındaki mesafeli ilişki & 14 & 7,8 \\
\hline Hocanın alan yetersizliği & 7 & 3,9 \\
\hline Hocanın formasyon yetersizliği & 11 & 6,1 \\
\hline Diğer & 27 & 15,0 \\
\hline \multicolumn{1}{|c|}{ Toplam } & 147 & 81,7 \\
\hline
\end{tabular}

Arapça dersi öğretim metodunu yetersiz ve doğru bulmayan ya da kısmen yeterli ve doğru bulan öğrencilere bunun nedeni sorulmuş ve $\% 48,9$ oranındaki öğrenciye göre ders anlatım yöntem ve tekniklerindeki yetersizlik, \%7,8 oranındaki öğrenciye göre hoca ve öğrenci arasındaki mesafeli ilişki, \%6,1 oranındaki öğrenciye göre hocanın formasyon eğitiminin yetersizliğ $i, \% 3,9$ oranındaki öğrenciye göre ise hocanın alan yetersizliği sebep olarak gösterilmiştir. Öğrencilerin \%15'ine göre ise diğer neden olarak: "Arapça dersinin hazırlikta ve 1. sinıf ile 2. sinıfta

41 Özenç, “Son Sınıf Öğrencilerine Göre Beklentileri Karşılama ve Mesleki Hayata Hazırlamada İlahiyat Fakültelerinde Eğitim (Dicle Üniversitesi Örneği)", 17.

42 Okumuş, "İlahiyat Fakültesi Öğrencilerinin Problemleri --Dicle Üniversitesi Örneği-”, 75.

43 Taştan v.dğr., “Üniversite Düzeyinde Din Öğretimi Alan Öğrencilerde Eğitim Sürecinde Oluşan Tutum ve Davranış Değişiklikleri (Erciyes Üniversitesi İlahiyat Fakültesi Örneği)"', 185. 
458 । İ. ERPAY / Öğrencilerin İlahiyat Fakültesine Yönelik Görüşleri

öğretilmesi, Arapça dersi veren hocaların Türkçe bilmemesi sonucu iletişim eksikliği, öğrencilerin seviyesine göre Arapça dersinin ă̆ır olması, Teori olarak anlatılıp pratiğe dökülmemesi, ders materyallerinin yetersizliği, ders kredisinin yetersizliği, derslerin işlenmesindeki yetersizlik, ögrencilerin ilgisiz olması ve yeterli düzeyde çalışma performansı göstermemeleri" göstermiştir.

Arapça öğretim metodunun doğru ve yeterli olmadığını belirten öğrencilerin büyük bir bölümü en önemli sorun olarak, ders anlatım yöntem ve teknikleri olarak belirtmektedir.

Tablo 27. İlahiyat Fakültesinin Eğitim İmkânlarının Öğrencilerin Beklentilerini Karşılama Durumu

\begin{tabular}{|l|c|c|}
\hline $\begin{array}{c}\text { İlahiyat Fakültesinin eğitim imkânları } \\
\text { beklentilerinizi karşılamada yeterli midir? }\end{array}$ & Kişi sayısı & Yüzde \\
\hline Beklentilerimi karşıladı & 14 & 7,8 \\
\hline Kısmen karşıladı & 131 & 72,8 \\
\hline Karşılamadı Toplam & 35 & 19,4 \\
\hline \multicolumn{1}{|c|}{ "Sirt } & 180 & 100,0 \\
\hline
\end{tabular}

Öğrencilere, "Siirt İlahiyat Fakültesinin eğitim imkânları beklentilerinizi karşıladı mı?" sorusu yöneltilmiş; öğrencilerin \%7,8'i beklentilerini karşıladığı, \%72,8'i kısmen karşıladığını ve \%19,4 oranındaki öğrenci ise karşılamadığ cevabını vermiştir.

Tablo 28. İlahiyat Fakültesinin Öğrencilerin Görüş Değişikliğindeki Etki Durumu

\begin{tabular}{|c|c|c|}
\hline \begin{tabular}{|c|} 
İlahiyat Fakültesine başlarken ki düşünceleriniz \\
ile mezun olurken ki düşünceleriniz arasında \\
bir değişiklik meydana geldi mi?
\end{tabular} & $\begin{array}{c}\text { Kişi } \\
\text { Sayısı }\end{array}$ & Yüzde \\
\hline Evet & 100 & 55,6 \\
\hline Hayır & 28 & 15,6 \\
\hline Kismen & 52 & 28,9 \\
\hline Toplam & 180 & 100,0 \\
\hline
\end{tabular}

Öğrencilerin \%55,6'sının ilahiyat fakültesine başlarken ki ile mezun olurken ki düşünceleri arasında bir değişim yaşanmış, \%15,6 oranındaki öğrencinin düşüncesinde herhangi bir değişim yaşanmamış ve \%28,9 oranındaki öğrencinin düşüncesinde ise kısmen bir değişim yaşanmıştır. 


\section{Tablo 29. İlahiyat Fakültesinin Öğrencilerin Görüş Değişikliğinde Etki} Durumunun Dağılımı

\begin{tabular}{|l|c|c|}
\hline $\begin{array}{c}\text { Cevap evet veya kısmen ise ne yönde bir değişiklik } \\
\text { olmuştur? }\end{array}$ & Kişi sayısi & Yüzde \\
\hline Kişilik, bilgi, görüş ve düşüncemde değişiklik oldu & 61 & 33,9 \\
\hline Daha çok okumaya ve kendimi geliştirmeye başladım & 21 & 11,7 \\
\hline Eleştirel bir düşünce yapısına sahip oldum & 51 & 28,3 \\
\hline Dine karşı ilgimde azalma oldu & 11 & 6,1 \\
\hline Diğer & 5 & 2,8 \\
\hline \multicolumn{1}{|c|}{ Toplam } & 149 & 82,8 \\
\hline
\end{tabular}

İlahiyat fakültesine karşı, ilk yıllar ile mezun olurken ki düşünceleri arasında değişim meydana gelen öğrencilere ne yönde bir değişim yaşandiğ 1 sorusu sorulduğunda; öğrencilerin \%33,9'u kişilik, bilgi, görüş ve düşünce değiş̧ikliği, \%28,3'ü eleştirel bir düşünce yapısına sahip olma, \%11,7'si daha çok okuma ve kendini geliştirmeye başlama, \%6,1'i dine karşı ilgide azalma yönünde olduğu cevabını vermişlerdir.

\section{Tablo 30. Öğrencilere Göre Aldıkları Eğitimin İlahiyat Öğrencisinin}

Sahip Olması Gereken Vasıflar Üzerindeki Etki Durumu

\begin{tabular}{|c|c|c|}
\hline $\begin{array}{c}\text { Fakülteden mezun olurken ilahiyat öğrencisinin sahip } \\
\text { olması gereken vasıflara sahip olduğunuzu } \\
\text { düşünüyor musunuz? }\end{array}$ & Kişi Sayısı & Yüzde \\
\hline Evet & 36 & 20,0 \\
\hline Kismen & 111 & 61,7 \\
\hline Hayır & 33 & 18,3 \\
\hline Toplam & 180 & 100,0 \\
\hline
\end{tabular}

Öğrencilerin \%20'si mezun olurken ilahiyat öğrencisinin sahip olması gereken vasıflara sahip olduğunu, \%61,7'si kısmen sahip olduğunu, \%18,3'ü ise sahip olmadığını belirtmiştir. Buna göre öğrenciler, büyük $(\% 81,7)$ oranda mezun olurken ilahiyat öğrencisinin sahip olması gereken vasıflara sahip olduklarını düşünmektedirler. 
460 I İ. ERPAY / Öğrencilerin İlahiyat Fakültesine Yönelik Görüşleri

Tablo 31. Öğrencilerin Mezuniyet Sonrası İlahiyat Fakültesi ile İlgili Düşünce Durumu

\begin{tabular}{|c|c|c|}
\hline $\begin{array}{c}\text { Mezuniyet Sonrası İlahiyat Fakültesi ile İlgili } \\
\text { Düşünceleri? }\end{array}$ & $\begin{array}{c}\text { Kişi } \\
\text { sayısı }\end{array}$ & Yüzde \\
\hline Memnum, çünkü.. & 89 & 49,4 \\
\hline Memnun değilim, çünkü... & 56 & 31,1 \\
\hline Pişmanım, çünkü... & 9 & 5,0 \\
\hline Diğer & 20 & 11,1 \\
\hline Cevaplamayan & 6 & 3,3 \\
\hline Toplam & 180 & 100,0 \\
\hline
\end{tabular}

Öğrencilerin mezuniyet sonrası ilahiyat fakültesi ile ilgili düşüncelerinin sorulduğu soruya $\% 49,4^{\prime} \ddot{u}$ ilahiyattan memnun olduğunu, \%31,1'i memnun olmadığını, \%5'i ilahiyata geldiğinden pişman olduğunu, \%11,1'i diğer seçeneği işaretlemişlerdir. Bu soruya cevap vermeyenlerin oranı ise \%3,3'tür. Açı uçlu olarak sorulmuş bu soruya "Memnunum, çünkü" diyenlerin bir kısmı memnuniyetlerinin nedenlerini belirtirken: "Dine dair bilmediği şeyleri öğrenme veya yanlış bildiği şeyleri düzeltme firsatı bulduğunu, yanlış din eğitiminin nelere sebebiyet verdiğinin farkına vardığını, hocaların ders anlatma konusunda çok iyi olduklarını, farklı bakış açısı kazandı̆̆ını, eğitim ortamının güzel olduğunu, eleştirel bir bakış açısı kazandığını, dini konularda farklı bir yaklaşım edindiğini, Arapça öğrendiğini, ilahiyatın fikir ve düşüncelerine katkısının çok büyük olduğunu, her açıdan daha donanımlı hale geldiğini, ilahiyatın okumayı sevdirdiğini, yeni arkadaş çevresi edindiğini, hayatına çok fazla etki ettiğini, ilahiyatın hedefleri için bir basamak olduğunu, ufkunun genişlediğini, ilahiyatta verilen eğitimden memnun kaldığını, hocaların öğrencilere karşı tutumlarının arkadaşça olduğunu, hocaların huzurlu, hocalarm donanımlı olduğunu, hocaların ilgi ve becerilerinin öğrenciye çok şey kattı̆̆ını, hocaların samimi olduklarını, dini ana kaynaklarından öğrendiğini, dini temsil eden ve öğrencileri ile arkadaş olabilen bir öğretmen olacă̆ını" ifadelerini kullanmışlardır.

İlahiyattan ayrılırken "Memnun değilim, çünkü" diyen öğrencilerden bazıları, memnun olmama nedenlerini: "Kendimi gerçekleştirmek için yeterli donanıma sahip olamadım", "öğrencilerin gelişimi için yeterli derecede firsat tanınmadı", "eğitim yeterince oturmamış", "yeterli bilgi birikimine sahip olmadan ayrullyorum", "yeterli olmayan bir eğitim 
aldım", "dersler yüzeyseldi", "bazı hocalar sürekli kendi görüşlerini aktardı", "öğretim elamanı hocalarımızın formasyon eksikliği sebebiyle dersler istenen seviyede geçmedi", "ezberci bir sistem vard ve gereksiz bilgiler verildi", "öğrenci seviyesi düşüktü", "dersler günlük hayattan kopuktu", "istemediğim bir ortamd, sınav sistemi ezbere dayalıydı", "çoğu hocalar zihinlere ket vurma çabasında ve kişiye göre davranış sergilemektedir", "alan derslerine yeterince ağırlık verilmedi ve bazı hocalar derslerden soğuttular", "teorik bir eğitim sistemi vardı", "öğrencinin aktif katılımı sağlayacak sosyal faaliyet eksikti", "toplumda karşılaştı̆̆ım sorunlar karşısında yeterince donanımlı hale gelmedim", "ait olduğum yer burası değil, az bir bilgi için çok emek vermek zorunda kaldım", "biz öğrenciler olarak derslere karşı ilgisizdik", "hocalar ise hep sınava yönelik çalıştırdılar", "karma eğitim yoktu ve toplumu sınıflara ayırma sorunu ile karşı karşıya kaldım", "yeteri kadar sorunları tartışma ve konuşma ortam bulamadım" ifadeleriyle dile getirmişlerdir.

İlahiyattan ayrılırken "Pişmanım, çünkü" diyenler: "Düşüncelerimi ifade etme becerim gelişmesi gerekirken köreldi", "münazara etme yetimi kaybettim", "bir an önce buradan kurtulmak istiyorum", "sürekli ezber ve bir şeylere mecbur bırakılmak çok sıktı", İstediŏim bölüm değildi, zorla okudum, keşke bu bölüme gelmeseydim, "beklediğim bir ortam olmadı", "öğrenciler önyargılı", "herkes diğerini kendilerine benzetmeye çalışıyorlar", "farklı düşünenler dışlanıyor bu da bizi olumsuz düşünmeye sevk etti" gibi fikirleri beyan etmişlerdir.

Mezuniyet sonrası ilahiyat fakültesi ile ilgili düşünceleri konusunda "Diğer" cevabını verenler ise: "Beni şaşırtacak pek bir şey öğrenmedim", "DGS ile geldiğimden derslerim sürekli çakışıyordu ve bazı derslerden tam verim alamadım", "program felsefe dersleri ile zenginleştirilip, hocaların ders anlatma teknikleri geliştirilebilir", "sorgulayıcı ve eleştirel bir ortam sağlanabilir", "tek cins eğitimin tek düze düşünceye sevk etmektedir", "kısmen memnun kaldım ama eğitimin yeterliliği konusunda beklediğimi alamadım", "ezber yöntemi kullanıldı̆̆ı için kendimi geliştirmede çok gayret etmemi gerektirdi", "bana bazı şeyler katarken benden bazı şeyler de aldi", "hocalar alanlarında yetkin olmalarına rağmen öğrenciye aktarmada sıkıntı yaşamaktalar çok zorlayıcı bir ortam, keyifliydi" gibi olumsuz veya olumlu ifadeler yer almıştır.

$\mathrm{Bu}$ veriler genel olarak incelendiğinde öğrencilerin büyük bir kısmının $(\% 49,4)$ ilahiyat fakültesinden memnun olduğu görülmektedir. Öğrencileri, din adına doğru bildikleri yanlışları düzeltme şansı 
462 I İ. ERPAY / Öğrencilerin İlahiyat Fakültesine Yönelik Görüşleri

bulmaları, farklı ve eleştirel bir bakış açısı kazanmaları ve hocaların öğrenciye karşı olumlu yaklaşımları memnun etmektedir.

Yapılan çalışmalara baktığımızda son sınıf öğrencilerinin mezuniyet sonrası belirsizlik ve endişenin etkisiyle genel memnuniyet düzeyinde bir azalma söz konusudur. ${ }^{44} \mathrm{Bu}$ bağlamda dördüncü sinıflar içerisinde memnun olmayanları dikkate aldığımızda $(\% 31,1)$ kendilerini yeterli derecede yetişmiş olarak görmemeleri memnun olmama nedeni olarak ön plana çıkmaktadır. Bununla birlikte yeni kurulan bir fakülte olması hasebiyle eğitimin yeterince oturtulamadı̆̆ı, gelen öğrencilerin seviyesinin düşük olması, teorik derslerin daha fazla olması, ders içeriklerinin günlük hayattan kopuk olması gibi nedenler memnuniyet düzeyini azaltmış görünmektedir.

İlahiyat fakültesine gelenlerden pişman olduğunu belirtenler azınlıkta olmakla beraber $(\% 11,1)$, genel olarak ilahiyat öncesi kendilerini daha yeterli bulanlar ile derslerin ezber şeklinde geçtiğini düşünenler, zorla ilahiyat okumak zorunda kalanlar ve sürekli bir şeylerin dikte edildiğini öne sürenler olmuştur. Gerek memnun olmayanlar gerekse de pişman olanlar göz önünde bulundurularak eğitim sisteminin oturtulması, ezberci yaklaşımdan olabildiğince uzak durulması, konuların günlük hayat ile daha fazla irtibatlandırılması, pedagojik formasyon eksikliği gibi sorunlar önemle üzerinde durulması gereken konular olarak karşımıza çıkmaktadır.

44 Koç, "İlâhiyat Fakültesi (İlâhiyat Lisans Programı) Öğrencilerinin Sorunları ve Beklentileri", 38. 
İ. ERPAY / The Views of the Students Towards the Faculty of Theology I 463

Tablo 32. Öğrencilerin Mezun Olduğu Okul Türü ile Mezuniyet Sonrası İlahiyat Fakültesinden Memnun Olma Değişkenleri Arasındaki İlişki

\begin{tabular}{|c|c|c|c|c|c|c|}
\hline & \multicolumn{4}{|c|}{$\begin{array}{l}\text { Mezuniyet Sonrası İlahiyat Fakültesi ile ilgili } \\
\text { Düşünceniz Nedir? }\end{array}$} & \multirow[b]{2}{*}{ Toplam } \\
\hline & & $\begin{array}{l}\text { Memnunum, } \\
\text { Çünkü... }\end{array}$ & $\begin{array}{l}\text { Memnun } \\
\text { Değilim, } \\
\text { Çünkü... }\end{array}$ & $\begin{array}{l}\text { Pişmanım, } \\
\text { Çünkü... }\end{array}$ & Diğer & \\
\hline \multirow{12}{*}{ 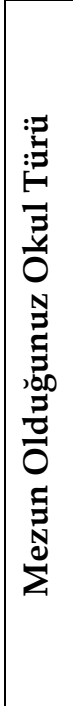 } & \multirow{3}{*}{ Düz Lise } & 19 & 20 & 3 & 4 & 46 \\
\hline & & $41,3 \%$ & $43,5 \%$ & $6,5 \%$ & $8,7 \%$ & $100,0 \%$ \\
\hline & & $10,9 \%$ & $11,5 \%$ & $1,7 \%$ & $2,3 \%$ & $26,4 \%$ \\
\hline & \multirow{3}{*}{$\begin{array}{l}\text { İmam } \\
\text { Hatip } \\
\text { Lisesi }\end{array}$} & 62 & 28 & 3 & 12 & 105 \\
\hline & & $59,0 \%$ & $26,7 \%$ & $2,9 \%$ & $11,4 \%$ & $100,0 \%$ \\
\hline & & $35,6 \%$ & $16,1 \%$ & $1,7 \%$ & $6,9 \%$ & $60,3 \%$ \\
\hline & \multirow{3}{*}{$\begin{array}{c}\text { Meslek } \\
\text { Lisesi }\end{array}$} & 4 & 5 & 2 & 3 & 14 \\
\hline & & $28,6 \%$ & $35,7 \%$ & $14,3 \%$ & $21,4 \%$ & $100,0 \%$ \\
\hline & & $2,3 \%$ & $2,9 \%$ & $1,1 \%$ & $1,7 \%$ & $8,0 \%$ \\
\hline & \multirow{3}{*}{$\begin{array}{c}\text { Açık } \\
\text { Öğretim } \\
\text { Lisesi }\end{array}$} & 4 & 3 & 1 & 1 & 9 \\
\hline & & $44,4 \%$ & $33,3 \%$ & $11,1 \%$ & $11,1 \%$ & $100,0 \%$ \\
\hline & & $2,3 \%$ & $1,7 \%$ & ,6\% & ,6\% & $5,2 \%$ \\
\hline \multirow{3}{*}{\multicolumn{2}{|c|}{ oplam }} & 89 & 56 & 9 & 20 & 174 \\
\hline & & $51,1 \%$ & $32,2 \%$ & $5,2 \%$ & $11,5 \%$ & $100,0 \%$ \\
\hline & & $51,1 \%$ & $32,2 \%$ & $5,2 \%$ & $11,5 \%$ & $100,0 \%$ \\
\hline
\end{tabular}

Öğrencilerin mezun olduğu ortaöğretim okul türü ile ilahiyat fakültesinden mezuniyetleri sonrası düşünce değişkenleri incelendiğinde düz liseden mezun olan öğrencilerin \%41,3'ünün memnun, \%6,5'inin pişman olduğu ve \%43,5'inin ise memnun olmadı̆̆ı; imam hatip lisesi mezunu öğrencilerin \%59'unun memnun, \%2,9'unun pişman ve \%26,7'sinin memnun olmadığ1 sonucuna ulaşılmıştır. Ayrıca meslek lisesi mezunu öğrencilerin \%28,6'sının memnun, \%14,3'ünün pişman olduğu; açık öğretim lisesi mezunu öğrencilerin ise \%44,4'ünün memnun, \%11,1'inin pişman olduğu ve \%33,3'ünün ise memnun olmadığ1 görülmektedir. Buna göre mezun olunan orta öğretim türü ile ilahiyat fakültesinden mezuniyet sonrası düşüncelerinin çok fazla 
464 I İ. ERPAY / Öğrencilerin İlahiyat Fakültesine Yönelik Görüşleri

değişkenlik göstermediği; ancak imam hatip lisesi ile açık öğretim lisesi mezunu öğrencilerin ilahiyat fakültesinden mezun olmanın memnuniyetinin daha yüksek olduğunu, düz lise ve meslek lisesi mezunu öğrencilerde ise memnuniyetsizlik düzeyinin yüksek olduğunu söylemek mümkündür. Pişman olanların oranına baktığımızda meslek lisesi mezunları ile açık öğretim lisesi mezunlarının oranları yüksek ve birbirine yakın olduğunu görmekteyiz.

Tablo 33. Öğrencilerin İlahiyat Fakültesini Seçme Nedenlerine Göre Mezuniyet Sonrası İlahiyat Fakültesine İlişkin Düşünceleri

\begin{tabular}{|c|c|c|c|c|c|c|}
\hline & & \multicolumn{4}{|c|}{$\begin{array}{l}\text { Mezuniyet Sonrası İlahiyat Fakültesi ile İlgili } \\
\text { Düşünceniz Nedir? }\end{array}$} & \multirow[b]{2}{*}{ Toplam } \\
\hline & & $\begin{array}{c}\text { Memnunum, } \\
\text { Çünkü.. }\end{array}$ & $\begin{array}{l}\text { Memnun Değilim, } \\
\text { Çünkü... }\end{array}$ & $\begin{array}{l}\text { Pişmanım, } \\
\text { Çünkü... }\end{array}$ & $\begin{array}{c}\text { Diğer } \\
\text { (Belirtiniz) }\end{array}$ & \\
\hline \multirow{21}{*}{ 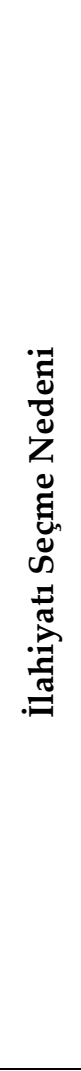 } & \multirow{3}{*}{$\begin{array}{l}\text { Ailem İstediği } \\
\text { İçin }\end{array}$} & 16 & 11 & 2 & 4 & 33 \\
\hline & & $48,5 \%$ & $33,3 \%$ & $6,1 \%$ & $12,1 \%$ & $100,0 \%$ \\
\hline & & $9,2 \%$ & $6,3 \%$ & $1,1 \%$ & $2,3 \%$ & $19,0 \%$ \\
\hline & \multirow{3}{*}{$\begin{array}{c}\text { Dinimizi } \\
\text { Doğru ve } \\
\text { Kapsamlı } \\
\text { Öğrenmek İçin }\end{array}$} & 36 & 13 & 0 & 6 & 55 \\
\hline & & $65,5 \%$ & $23,6 \%$ &, $0 \%$ & $10,9 \%$ & $100,0 \%$ \\
\hline & & $20,7 \%$ & $7,5 \%$ &, $0 \%$ & $3,4 \%$ & $31,6 \%$ \\
\hline & \multirow{3}{*}{$\begin{array}{c}\text { Daha Kolay } \\
\text { Meslek Sahibi } \\
\text { Olmak İçin }\end{array}$} & 6 & 7 & 2 & 2 & 17 \\
\hline & & $35,3 \%$ & $41,2 \%$ & $11,8 \%$ & $11,8 \%$ & $100,0 \%$ \\
\hline & & $3,4 \%$ & $4,0 \%$ & $1,1 \%$ & $1,1 \%$ & $9,8 \%$ \\
\hline & \multirow{3}{*}{$\begin{array}{l}\text { Dine Hizmet } \\
\text { İçin }\end{array}$} & 12 & 6 & 0 & 1 & 19 \\
\hline & & $63,2 \%$ & $31,6 \%$ &, $0 \%$ & $5,3 \%$ & $100,0 \%$ \\
\hline & & $6,9 \%$ & $3,4 \%$ &, $0 \%$ & $6 \%$ & $10,9 \%$ \\
\hline & \multirow{3}{*}{$\begin{array}{l}\text { Öğretmen } \\
\text { Olmak İçin }\end{array}$} & 13 & 8 & 2 & 5 & 28 \\
\hline & & $46,4 \%$ & $28,6 \%$ & $7,1 \%$ & $17,9 \%$ & $100,0 \%$ \\
\hline & & $7,5 \%$ & $4,6 \%$ & $1,1 \%$ & $2,9 \%$ & $16,1 \%$ \\
\hline & \multirow{3}{*}{$\begin{array}{c}\text { Sinav } \\
\text { Sisteminden } \\
\text { Dolayı }\end{array}$} & 4 & 7 & 3 & 1 & 15 \\
\hline & & $26,7 \%$ & $46,7 \%$ & $20,0 \%$ & $6,7 \%$ & $100,0 \%$ \\
\hline & & $2,3 \%$ & $4,0 \%$ & $1,7 \%$ & $6 \%$ & $8,6 \%$ \\
\hline & \multirow{3}{*}{ Diğer } & 2 & 4 & 0 & 1 & 7 \\
\hline & & $28,6 \%$ & $57,1 \%$ &, $0 \%$ & $14,3 \%$ & $100,0 \%$ \\
\hline & & $1,1 \%$ & $2,3 \%$ &, $0 \%$ &, $6 \%$ & $4,0 \%$ \\
\hline \multirow{3}{*}{\multicolumn{2}{|c|}{ Toplam }} & 89 & 56 & 9 & 20 & 174 \\
\hline & & $51,1 \%$ & $32,2 \%$ & $5,2 \%$ & $11,5 \%$ & $100,0 \%$ \\
\hline & & $51,1 \%$ & $32,2 \%$ & $5,2 \%$ & $11,5 \%$ & $100,0 \%$ \\
\hline
\end{tabular}


İlahiyat fakültesi eğitimi sürecinde öğrencilerin memnuniyet durumu ilahiyatı seçme nedeni değişkeni ile ilişkilendirildiğinde; aile isteği ile gelen öğrencilerin \%48,5'inin memnun olduğu, \%33,3'ünün memnun olmadığı, \%6,1'inin pişman olduğu ve \%12,1'inin ise diğer görüşte olduğu görülmektedir. Dini daha doğru ve kapsamlı öğrenmek amacı ile gelen öğrencilerin \%65,5'inin memnun olduğu, \%23,6'sının memnun olmadığı, \%10,9'unun diğer görüşte olduğu; daha kolay meslek sahibi olmak için tercih eden öğrencilerin ise \%35,3'ünün memnun olduğu, \%41,2'sinin memnun olmadığı, \%11,8'inin pişman olduğu; dine hizmet etmek amacı ile İlahiyat fakültesini tercih eden öğrencilerin $\% 63,2$ 'sinin memnun olduğu, \%31,6'sının memnun olmadığı; öğretmen olmak amacı ile ilahiyat fakültesini tercih eden öğrencilerin $\% 46,4^{\prime}$ ünün memnun olduğu, \%28,6'sının memnun olmadığı, \%7,1'inin pişman ve $\% 1,9^{\prime}$ nun diğer görüşte olduğu; sinav sisteminden dolayı bu fakülteyi tercih eden öğrencilerin \%26,7'sinin memnun olduğu, \%46,7'sinin memnun olmadığ1,\%20'sinin pişman olduğu belirlenmiştir. Diğer gerekçelerle tercih eden öğrencilerin \%28,6'sının memnun olduğu, $\% 57,2$ 'inin memnun olmadığı, \%14,3'ünün diğer görüşte olduğu görülmektedir. Ayrıca dini doğru ve kapsamlı öğrenmek ve dine hizmet etmek amacı ile ilahiyat fakültesini tercih eden öğrenciler ile diğer sebeplerden dolayı tercih eden öğrenciler içerisinde pişman olan öğrencinin olmadığı sonucuna ulaşılmıştır.

Tabloda aile isteği, daha kolay meslek sahibi olmak ve sınav sisteminden dolayı ilahiyatı tercih edenlerin ilahiyat sonrası düşüncelerine bakıldığında büyük oranda ilahiyattan memnun olmadıkları görülmektedir. Bu da ilahiyatı kendi iradeleri ile tercih etmeyen veya farklı amaç ile ilahiyata gelenlerin daha çok memnuniyetsiz olduğu sonucunu çıkarmaktadır. Bunun yanı sıra dini doğru ve kapsamlı öğrenmek, dine hizmet ve öğretmen olmak amaciyla ilahiyatı tercih edenlerde mezuniyet sonrası ilahiyattan memnun olma durumları yüksektir. 
466 I İ. ERPAY / Öğrencilerin İlahiyat Fakültesine Yönelik Görüşleri

Tablo 34. Öğrencilerin İlahiyat Fakültesi Eğitim Sürecinde Herhangi Bir Dersten Uzaklaşma veya Derse Karşı İlgilerinin Azalma Durumu

\begin{tabular}{|c|c|c|}
\hline $\begin{array}{l}\text { İlahiyat Fakültesin eğitim sürecinde } \\
\text { herhangi bir dersten uzaklaştığınız veya } \\
\text { derse karşı ilginizin azaldığı oldu mu? }\end{array}$ & Kişi sayısı & Yüzde \\
\hline Evet & 109 & 60,6 \\
\hline Hayır & 71 & 39,4 \\
\hline Toplam & 180 & 100,0 \\
\hline
\end{tabular}

Araştırma kapsamındaki öğrencilerin eğitim sürecinde herhangi bir dersten uzaklaşma ya da ilgilerinin azalma durumu incelendiğinde öğrencilerin \%60,6'sının evet, \%39,4'nün hayır cevabı verdiği görülmektedir.

Tablo 35. Öğrencilerin Eğitim Sürecinde Uzaklaştığı ya da İlgilerinin Azaldığı Dersler

\begin{tabular}{|l|c|c|}
\hline \multicolumn{1}{c|}{ Dersler } & Evet $\%$ & Hayir \\
\hline Din Sosyolojisi & 1,1 & 98,9 \\
\hline Tasavvuf & 2,2 & 97,8 \\
\hline İnkılap Tarihi & 1,1 & 98,9 \\
\hline İslam Tarihi & 3,3 & 96,7 \\
\hline Mantık & 1,1 & 98,9 \\
\hline Felsefe & 3,9 & 96,1 \\
\hline Din Hizmetlerinde Rehberlik ve İletişim & 1,7 & 98,3 \\
\hline Özel Öğretim Yöntemleri & 1,7 & 98,3 \\
\hline Din Eğitimi & 3,3 & 96,7 \\
\hline Tefsir & $\mathbf{8 , 9}$ & 91,1 \\
\hline Kelam & 3,3 & 96,7 \\
\hline Arapça & $\mathbf{1 3 , 9}$ & 86,1 \\
\hline Formasyon & 3,3 & 96,7 \\
\hline Fikıh & $\mathbf{7 , 8}$ & 92,2 \\
\hline Hadis & $\mathbf{2 9 , 4}$ & 70,6 \\
\hline Osmanlıca & $\mathbf{1 , 1}$ & 98,9 \\
\hline Kuran & $\mathbf{1 0 , 0}$ & 90,0 \\
\hline
\end{tabular}

"İlahiyat fakültesin eğitim sürecinde herhangi bir dersten uzaklaştı̆̆ııız veya derse karşı ilginizin azaldı̆̆ı oldu mu?" sorusuna evet cevabını veren öğrencilerin \%29,4’ü Hadis, \%13,9’u Arapça, \%10’u Kuran, \%7,8'i F1kıh, $\% 8,9^{\prime} u$ ise Tefsir derslerine karşı ilgilerinin azaldığını ya da bu derslerden uzaklaştıklarını belirtmişlerdir. 


\section{Sonuç, Tartışma ve Öneriler}

2018-2019 öğretim yılı Siirt Üniversitesi İlahiyat Fakültesi son sinıf öğrencileri üzerinde uygulanan bu anket çalışmasında öğrencilerin müfredata, öğretim durumuna, öğretim ortamına karşı tutumları ile öğretim sürecinde etkin olan idare ve öğretim elemanlarına karşı alg1 durumları ortaya konmaya çalışılmıştır. Bu bağlamda ortaya çıkan sonuçlar şu şekildedir:

İlahiyat fakültesi lisans programını tercih eden öğrencilerin cinsiyet durumlarına baktığımızda kadın oranının, erkek öğrencilere göre daha fazla olduğunu söyleyebiliriz. Bu sonuç son yıllarda kız öğrencilerin ilahiyat fakültelerini erkeklerden daha fazla tercih ettiklerine ilişkin YÖK'ün istatistiki verileriyle de örtüşmektedir.

İlahiyatı tercih eden öğrencilerin mezun oldukları okul türüne baktığımızda son yıllarda imam hatip liseleri haricinde, düz lise ve meslek lisesinden gelenlerin sayısında artış olduğu gözlenmektedir. İlahiyat fakültesinde okuyan son sınıf öğrencilerinin \%40'nı düz lise, meslek lisesi ve açık öğretim lisesi mezunları oluşturmaktadır. Bu da önceden sadece imam hatip lisesi mezunlarınca tercih edilmek zorunda bırakılan ilahiyatların son zamanlarda diğer liselerden gelenlerle daha renkli bir öğrenci profiline sahip olmaya başladığını ortaya koymaktadır.

Öğrencilerin ilahiyatı tercih etme nedenlerine baktığımızda kendi iradeleri dışında ve mesleki kaygı kategorisinde değerlendirebileceğimiz ailelerin isteği, daha kolay meslek sahibi olmak, öğretmen olmak ve sinav sisteminden dolayı ilahiyatı tercih edenlerin oranı \%52,7'yi oluşturmaktadır. İlahiyatı tercih nedenleri arasında dini kaygı ve dini amaç kategorisinde değerlendirebileceğimiz, dinimizi doğru ve kapsamlı öğrenmek ve dine hizmet için tercih edenlerin oranı \% $43,4^{\prime}$ tür. Ancak ilahiyatı imam olmak için tercih eden son sınıf öğrencisi bulunmamaktadır. Son yıllarda ailelerin (özellikle kız) çocuklarını ilahiyata yönlendirme oranlarında artış gözlenirken sınav sisteminden dolayı ilahiyatı tercih edenlerin oranında azalma gözlenmektedir.

Öğrencilere göre fakültede yürütülen derslerde uygun yöntem ve teknikler ile materyallerin kullanım durumlarına verilen cevaplar iki kategoride değerlendirildiğinde; birinci kategoriyi oluşturan her derste veya çoğu derste uygun yöntem ve teknikler ile materyallerin kullanılmakta olduğunu söyleyenlerin oranı 16,1'de kalırken, ikinci kategorideki çok az derste kullanılmakta diyenler ile hayır, kullanılmamakta diyenlerin oranı $\% 83^{\prime} 9^{\prime}$ dur. Bunun yanı sıra öğretim 
468 | İ. ERPAY / Öğrencilerin İlahiyat Fakültesine Yönelik Görüşleri

elemanlarının yeterliliği ve deneyimi konusunda bütün öğretim elemanları alanında yeterlidir diyenler ile çoğu öğretim elemanları alanında yeterli diyenlerin oranı \%66,6'ya ulaşırken, çok az öğretim elemanı alanında yeterlidir diyenler ile hayır, öğretim elemanları alanında yeterli değil diyenlerin oranı \%33,4'de kalmıştır. Çalışmaya katılan öğrenciler tarafından genel olarak öğretim elemanları alanında yeterli görülürken, derslerde uygun yöntem ve teknikler ile materyallerin kullanımı konusunda yetersiz bulunmaktadır. Diğer taraftan öğrencilerin, öğretim elamanı ve idare ile ilişkilerine baktığımızda rahat hissedenlerin $(\% 75,6)$ oranı oldukça yüksektir.

İlahiyatta almış olduğu eğitimi yeterli görenlerin oranı $(\% 56,7)$, almış olduğu eğitimi yetersiz görenlerin oranına $(\% 43,3)$ göre daha yüksektir. İlahiyatta aldığı eğitimi yeterli görmeyenlerin nedenlerine bakıldığında birinci sırada ders hocalarının formasyon eksikliği ile ikinci sırada müfredattaki derslerin saat ve kredilerinin yetersizliği yer almaktadır. Bazıları da ders sayısının fazlalığından yakınmaktadır.

Öğrencilerin ilahiyattaki öğretim ortamına ilişkin görüşleri değerlendirildiğinde öğretim ortamını sağlıklı, rahat, keyifli, demokratik ve özgür bulanların oranı $(\% 38,3)$ düşük iken, baskıc1, sıkıc1, zorlayıcı bulanların oranı $(\% 61,6)$ yüksektir. Açık öğretim lisesi mezunlarının çoğunluğu ilahiyat ortamını rahat, özgür ve sağlıklı bulurken, düz lise ve mesleki lise mezunlarının çok azı ilahiyat ortamını rahat, özgür ve sağlıklı görmektedir. İmam hatip lisesi mezunlarının \%55,6's1 sıkıc1, baskıcı, zorlayıcı bulurken, $\% 44,4$ 'ü rahat, sağlıklı, demokratik ve özgür bir ortam olarak değerlendirmektedir.

Katılımcllar verilmekte olan felsefe (\%85) ve formasyon $(\% 97,2)$ derslerini ilahiyat içerisinde gerekli görmekte ve yararlı olduğunu düşünmektedir. Ancak imam hatip lisesi mezunları ile açık öğretim lisesi mezunları içerisinde felsefe dersinden zorlananların oranı, düz lise mezunlarının oranları ile karşılaştırıldığında daha fazla iken, Temel İslam Bilimlerinden zorlanan düz lise ve meslek liselilerin oranı, imam hatip lisesi ve açı öğretim lisesi oranına göre daha yüksektir. Öğrencilerin Arapça öğretimini yeterli bulma durumlarına bakıldığında yeterli ve kısmen yeterli bulanlar $(\% 49,4)$ ile yeterli bulmayanların $(\% 50,6)$ oranı birbirine çok yakındır. Arapça öğretimini yeterli bulmayanların çoğunluğu $(\% 48,9)$ ders anlatım yöntem ve tekniklerinin yetersizliğini öne sürmekte iken çok azı $(\% 3,9)$ ders hocalarının Arapça alan yetersizliğinden kaynaklandığını düşünmektedir. 
İlahiyat son sınıf öğrencileri eğitim gördükleri sırada bazı derslerden uzaklaştıkları veya bazı derslere karşı ilgilerinin azaldığını belirtmişlerdir.

Son sınıf öğrencilerimiz ilahiyattaki eğitim imkanlarının beklentilerini büyük oranda karşıladığını düşünmektedir. Aynı zamanda ilahiyatta okumak, öğrencilerde büyük oranda $(\% 84,4)$ görüş değişikliğine neden olmuştur. Bu görüş değişikliğini en çok kişilik ve bilgi değişikliği ile eleştirel bir düşünce yapısına sahip olma olarak nitelendirmişlerdir. Öğrencilerin ilahiyattan memnuniyet durumlarına bakıldığında memnun olanların oranı $(\% 49,4)$, memnun olmayan oranından $(\% 31,1)$ daha yüksektir. Bu arada çok az oran da olsa (\%5) ilahiyat okumaktan pişman olduğunu belirtenler olmuştur. İlahiyat okumaktan pişman olanların mezun olduğu lise türüne baktığımızda meslek lisesi başta olmak üzere sırasıyla açı öğretim lisesi ve düz lise mezunları görülmektedir.

Araştırma sonuçlarına göre elde edilen veriler ışığında öğrenci beklentilerini ve önerilerini dikkate alarak şu önerilerde bulunabiliriz:

Öğrencilerin ailelerinin büyük bir çoğunluğunun gelir durumları düşük ve orta kesime sahip olmaları onların ekonomik anlamda desteklenmeleri gerektiğini ortaya koymaktadır. Ailelerin ekonomik olarak yetersiz durumda olması öğrencileri sanat, sosyal, kültürel ve sportif aktivitelerde bulunmada sınırlayacağı için bu alanlarda öncülük edilmeli, ortamlar sunulmalıdır. Öğrencilerin her açıdan gelişmeleri için fırsatlar tanınmalı, öğrencilere fikirlerini özgürce söyleyebilecekleri platformular oluşturulmalı, öğrenciler için fakülte sıkıcı bir eğitim kurumu olmaktan çıkartılmalı, eğitim ile beraber sosyalleşmenin birlikte yürütüldüğ̈̈ yer haline getirilmelidir. Bu konularda öğrenci ile işbirliği halinde olunmalı, idare ve öğrenci arasındaki bağ güçlendirilmeli, gerekirse fakülte öğrenci temsilcisi fakülte yönetim kurulları içerisinde yer almalıdır.

Derslerin güncel konularla ilişkilendirilmesi, öğrencilerin derse ilgisini çekme konusunda önemlidir. Bunun yanı sıra dersler içerik olarak zenginleştirilmeli, ders materyalleri güncellenmeli, ders anlatım araç ve gereçleri açısından konulara uygun olarak çeşitlendirilmelidir. Öğrencilerin dersi anlamadaki farklılıkları dikkate alınarak derslerde olabildiğince farklı yöntem ve teknikler uygulanmalıdır. Öğrenciler için mekanik öğrenme yerine hayatta gerekli olacak ve uygulayacak anlamlı öğrenmeye ihtiyaç vardır. Sınavlarda ezberi teşvik edici, bilgi ölçücü 
470 | İ. ERPAY / Öğrencilerin İlahiyat Fakültesine Yönelik Görüşleri

sorulardan ziyade zihin açıcl, düşünmeye sevk eden sorular sorulmalıdır. Öğrencilerin derslere aktif katılımı sağlanmalı, sadece sunuş stratejisi değil gerektiğinde sorgulayıcı bir yaklaşımla araştırma ve inceleme stratejisi gibi çeşitli stratejiler uygulanmalıdır.

Öğrencilerin Arapça dersinden zorlandıkları görülmektedir. Arapça öğretiminde dil öğretim yöntemleri uygulanmalı, yeni ders materyalleri ile yöntem ve teknikler belirlenmelidir. Arapça dersinde teori ile beraber uygulamaya da önem verilmeli, hazırlık sonrasında yeterli kredide Arapça dersleri ile desteklenmelidir.

Öğrencilerin bir kısmı ders saati ve kredilerinin yetersizliğinden ve müfredatın derinlemesine ders işlenmesine mani bir durum olduğundan bahsetmektedir. Mevcut ilâhiyat lisans programı bir taraftan Diyanet İşleri Başkanlığına din hizmetlileri yetiştirirken, bir taraftan da Milli Eğitime öğretmen yetiştirmektedir. Ancak mevcut durumda Diyanet İşleri Başkanlığı 4-6 yaş arası çocuklara din eğitimi faaliyetine başlamıştır. Ancak ilahiyat mezunları çocukların gelişim özeliklerine göre bir eğitime sahip olmadıkları için buralarda doğrudan çalışamamakta, çeşitli sertifika programları ile bu eğitim kurumlarına uygun hale getirilmeye çalışılmaktadır. $\mathrm{Bu}$ durum ilahiyat programlarının yeniden gözden geçirilmesini, günün şartlarına göre düzenlenmesini gerektirmektedir. İlahiyatlarda hizmet alanlarına göre müfredatlar oluşturulmalı, öğrenciler çalışacakları kurumlara göre dersler almalı ve daha çok uygulamaya yönelmelidir.

Sonuç olarak bu çalışmada Siirt İlahiyat Fakültesi öğrencilerinin görüşleri, sorunları ve ilahiyat algıları doğrultusunda değerlendirmelerde bulunulmuş, ilahiyatta yapılmakta olan eğitimöğretim, sosyal ve kültürel faaliyetler, öğretim durumu, müfredat ve eğitim ortamları ile öğretim yöntem ve teknikleri öğrenci gözünden aktarılmaya çalışılmıştır. Eğitimin tarafı olan öğrencinin yüksek din eğitimi ortamları olan ilahiyatların şekillenmesinde rol oynaması gelişim, dönüşüm ve ideal bir yüksek din eğitim kurumu haline gelmesi için önem arz etmektedir. 


\section{Kaynakça}

Cebeci, Suat. "Cumhuriyet Dönemi Yüksek Öğretimde Din Eğitimi". Ankara Üniversitesi İlahiyat Fakültesi Dergisi 39/2 (1999).

Demircan, Adnan. Türkiye'nin İlahiyat Sorunu. İstanbul: Beyan, 2015.

“Diyanet İşleri Başkanlığı 2017 Yılı İstatistikleri”. Erişim: 21 Mart 2019.

https://stratejigelistirme.diyanet.gov.tr/sayfa/57/istatistikler.

Doğan, M. Kadir - Yuret, Tolga. "Üniversitelere Yerleşmede Farklı Katsayı Uygulamasının Etkileri". Ankara Üniversitesi SBF Dergisi 70/1 (2015).

Gül, Ali Rıza. "Yüksek Din Eğitimi Kurumlarında Değişim ve Yenilenmenin Gerekçeleri". Eskişehir Osmangazi Üniversitesi İlahiyat Fakültesi Dergisi 5 (2016): 7-38.

Gün, Ayşegül. “Öğrencilerin Mesleki Yeterlilik Algıları ve Pedagojik Formasyon Programına İlişkin Görüşleri: Amasya Üniversitesi Örneği". Amasya Üniversitesi İlahiyat Fakültesi Dergisi 4/8 (30 Haziran 2017): 125-171.

Güneş, Adem. “İlahiyat Fakültesi Öğretim Elemanlarının Lisans Düzeyindeki Derslerde Yöntem ve Materyal Kullanma Durumları". İstanbul Üniversitesi İlahiyat Fakültesi Dergisi 29/1 (15 Haziran 2018): 71-93.

Kaya, Mevlüt - Nazıroğlu, Bayraramali. "İlahiyat Fakültelerinde Pedagojik Formasyon Derslerinin Tarihi Gelişimi". Modern Dönemde Illahiyat Ĕ̆itimi, Müfredatı ve Yöntem Tartışmaları (Uluslararası Katılımlı Çalıştay). 2010.

Koç, Ahmet. "İlâhiyat Fakültesi (İlâhiyat Lisans Programı) Öğrencilerinin Sorunları ve Beklentileri”. M.Ü. İlâhiyat Fakültesi Dergisi 25 (2003): 25-64.

Korkmaz, Mehmet. Din Öğretimi Teknolojisi ve Materyal Geliştirme. Kayseri: Kimlik Yayınları, 2017.

Korkmaz, Mehmet. "İlahiyat Fakültesi Öğrencilerinin Fakülteyi Tercih Nedenleri: Erciyes Üniversitesi İlahiyat Fakültesi Örneği". Bilimname 2010/1 (01 Mart 2010).

Köylü, Mustafa. "OMÜ İlahiyat Fakültesine Devam Eden Yabanc1 Uyruklu Öğrencilerin Fakülte Hakkındaki Düşünce, Sorun ve Beklentileri". Ondokuz Mayıs Üniversitesi İlahiyat Fakültesi Dergisi 12/12-13 (2001): 131-153.

Okumuş, Ejder. "İlahiyat Fakültesi Öğrencilerinin Problemleri -Dicle Üniversitesi Örneği-". Değerler Eğitimi Dergisi 5/13 (2007): 59-94. 
472 | İ. ERPAY / Öğrencilerin İlahiyat Fakültesine Yönelik Görüşleri

Özenç, Ali. “Son Sınıf Öğrencilerine Göre Beklentileri Karşılama ve Mesleki Hayata Hazırlamada İlahiyat Fakültelerinde Eğitim (Dicle Üniversitesi Örneği)". International Journal of Kurdish Studies 3/January (2017): 1-30.

Özkal, Uğur Ümmiye. Üniversite Öğrencileri Arasında Zorbalık ve Zorbalı̆̆ı̆n Psikolojik Sorunlarla İlişkisi (Yüksek Lisans Tezi, Ankara Üniversitesi, 2011.

Subaşı, Necdet. "İlahiyat Nedir". Tezkire, Düşünce, Siyaset, Sosyal Bilim Dergisi 31-32 (2003): 65-74.

Taşkıran, Ayşe. “İlahiyat Fakültesi Müfredatında Felsefe ve Din Bilimleri

Bölümü Derslerinin Yeri ve Fonksiyonlarına Dair Bir Araştırma (İlahiyat Fakültesi Öğrencileri Örneği)". Kahramanmaraş Sütçü İmam Üniversitesi İlahiyat Fakültesi Dergisi. 22 (02 Aralık 2013): 238-266.

Taştan, Abdulvahap - Kuşat, Ali - Çelik, Celaleddin. "Üniversite Düzeyinde Din Öğretimi Alan Öğrencilerde Eğitim Sürecinde Oluşan Tutum ve Davranış Değişiklikleri (Erciyes Üniversitesi İlahiyat Fakültesi Örneği)". Erciyes Üniversitesi Sosyal Bilimler Enstitüsü Dergisi 1/11 (01 Aralık 2001): 169-192.

Taştekin, Osman. "Yeni Kurulan İlahiyat Fakültelerinin Öğrenme Ortamına Yönelik Öğrenci Algıları". Usîul İslam Araştırmaları 19 (2013): 139-184.

Toktaş, Fatih - Acuner, H. Yusuf. "İlahiyat Fakültelerinde Felsefe Dersleri Ondokuz Mayıs Üniversitesi İlahiyat Fakültesi Örneği". Ondokuz Mayıs Üniversitesi İlahiyat Fakültesi Dergisi 17 (01 Eylül 2004): 159176.

Tosun, Cemal. Din Eğitimi Bilimine Giriş. Ankara: Pegem Akedemi, 2002.

Tural, Necla Kurul. “Öğrenci Başarısında Etkili Okul Değişkenleri ve Eğitimde Verimlilik". Ankara Universitesi Egitim Bilimleri Fakultesi Dergisi 1/35 (2002): 001-016.

Turan, İbrahim. "Din Görevlilerinin Mesleki Yeterlilikleri". Dinbilimleri Akademik Araştırma Dergisi 13/3 (01 Haziran 2013): 47-73.

Turan, İbrahim - Nazıroğlu, Bayramali. “İlahiyat Fakültesine Yeni Gelen Öğrencilerin Sorun ve Beklentileri: OMÜ İlahiyat Fakültesi Örneği". Journal of International Social Research. 2015.

Uçar, Recep. "İlahiyat Fakültesi Öğrencilerinin Profili, Akademik Eğilimleri ve Aldıkları Eğitime İlişkin Memnuniyet Algıları (İnönü Üniversitesi Örneği)". İnönü Üniversitesi İlahiyat Fakültesi Dergisi 8/2 (27 Aralık 2017): 97-170. 
İ. ERPAY / The Views of the Students Towards the Faculty of Theology | 473

Yavuz, Emrah. "Köy İmamlarının Görev Yaptıkları Yerleşim Biriminin Fiziki ve Sosyokültürel Yapısından Kaynaklanan Problemleri Üzerine Sosyolojik Bir İnceleme -Kayseri Pınarbaşı Örneği-". Dini Araştırmalar 18/47 (2016): 172-197.

Yıldız, Murat. İlahiyat Fakültesi Öğrencilerinin Psikososyal Özellikleri. İzmir: Tibyan Yayıncilik, 2003.

"YÖK Başkanlığı, İlahiyat Formasyon Programları, 23.06.2017 tarihli 75850160-104.01.07.01-434446 say1l yazıs1". 2017.

"Yükseköğretim Kurulu,Yükseköğretim Bilgi Yönetim Sistemi". Erişim: 16 Mart 2019. https://istatistik.yok.gov.tr/. 